УДК 551.078

\title{
МЕТАЛЛОГЕНИЯ КОНГИНСКОЙ ЗОНЫ ОМОЛОНСКОГО ТЕРРЕЙНА (Северо-Восток Азии)
}

\author{
Глухов А. Н., Прийменко В. В., Фомина М. И., Акинин В. В. \\ ФГБУН Северо-Восточный комплексный научно-исследовательский институт \\ им. Н. А. Шило ДВО РАН, г. Магадан \\ E-mail: gluhov76@list.ru
}

\begin{abstract}
Приведены новые данные о геологическом строении и составе рудопроявлений Конгинской магматической зоны, наложенной на Омолонский кратонный террейн (Северо-Восток Азии). Показано, что возраст и состав гранитоидов Конгинской зоны аналогичны вулканоплутоническим комплексам Охотско-Чукотского вулканогенного пояса (Пенжинский сегмент). Охарактеризованы рудопроявления медно-молибден-порфировой, золото-серебряной и серебро-полиметаллической формаций. Оруденение Конгинской зоны по составу близко месторождениям ОЧВП, отличаясь более высокими концентрациями молибдена в меднопорфировых рудах, а также преобладанием серебро-полиметаллического оруденения над золото-серебряным.
\end{abstract}

Ключевые слова: гранитоиды, минерализация, рудная формация.

DOI: $10.34078 / 1814-0998-2021-2-3-16$

В тыловой зоне Охотско-Чукотского вулканогенного пояса (ОЧВП) известен ряд далеко вдающихся в континент и вытянутых ортогонально по отношению к поясу магматических зон, сложенных вулкано-плутоническими ассоциациями мелового возраста. В ряде публикаций они получили наименование «зон тектоно-магматической активизации (ТМА)» (Кузнецов, 2006; Фадеев и др., 1990), хотя таковыми не являются, поскольку возраст магматизма в них такой же, как и в ОЧВП, не моложе. Одна из таких зон - Конгинская - рассекает Омолонский кратонный террейн $(\mathrm{OM})$ пополам и протягивается в глубь его на 150 км. Она сложена вулканическими ассоциациями андезидацитового состава и гранитоидами, геохимия и возраст которых не исследованы современными аналитическими методами. Изотопный возраст вулканических и интрузивных пород Конгинской зоны, определенный $\mathrm{K}-\mathrm{Ar}$ методом, колеблется от 59 до 118 млн лет (Горячев и др., 2017). С магматическими комплексами Конгинской зоны ассоциируют многочисленные рудопроявления $\mathrm{Au}, \mathrm{Ag}, \mathrm{Pb}, \mathrm{Zn}, \mathrm{Cu}, \mathrm{Mo}$. Они охарактеризованы в единичных публикациях (Пак, 2002; Горячев и др., 2017; Савва, 2018),

(С Глухов А. Н., Прийменко В. В., Фомина М. И., Акинин В. В., 2021 однако их геолого-генетическая принадлежность и возраст до конца неясны.

В настоящей статье впервые приводятся результаты исследований пород и руд рудопроявлений в Конгинской зоне методом ICP-MS, а также первые определения возраста минерализации ${ }^{40} \mathrm{Ar} /{ }^{39} \mathrm{Ar}$ методом.

\section{МЕТОДЫ ИССЛЕДОВАНИЙ}

Химический состав горных пород и руд изучался в лаборатории ООО «Стюарт Геокемикл нэд Эссей» (г. Москва). Содержания примесных элементов определяли окислительным разложением в четырех кислотах с последующим определением основных элементов методом атомноэмиссионной спектрометрии. Пределы обнаружения для $\mathrm{Cu}, \mathrm{Ni}, \mathrm{Co}, \mathrm{Pb}, \mathrm{Sc}, \mathrm{Li}$ составляют 0.1-0.5 ppm, для $\mathrm{Ag}, \mathrm{Mo}, \mathrm{Cd}-0.01-0.05 \mathrm{ppm}$. Определение примесных элементов проводили сплавлением с боратами перед кислотным растворением и последующим ICP-MS анализом. Правильность анализа контролировали путем измерения международных и российских стандартных образцов GSP_2, ВМ, СГД_1А, CT_1. Ошибки определения концентраций составляли от 3 до 5 мас. \% для большинства элементов. Содержания элементов определяли сплавлением с метаборатом лития с последующим растворением в 
смеси кислот и атомно-эмиссионной спектрометрией с индуктивно связанной плазмой (ICPAES). Пределы обнаружения для главных петрогенных оксидов составили 0.01-100 \%, для REE, Th, U - 0.01-0.05 ppm, W, Zr, Ba, Sr, Ta, Ce, Ga 0.1 ppm. Обработку петро- и геохимических данных и построение классификационных диаграмм проводили посредством свободно распространяемого программного пакета GCDkit (Janousek et al., 2006).

Возраст образования околорудных метасоматитов определяли ${ }^{40} \mathrm{Ar} /{ }^{39} \mathrm{Ar}$ методом в Аналитическом центре ИГМ СО РАН (г. Новосибирск) по монофракциям серицита. ${ }^{40} \mathrm{Ar} /{ }^{39} \mathrm{Ar}$ геохронологические исследования проводили методом ступенчатого прогрева (Травин и др., 2009). Навески образцов совместно с мусковитом МСA-11 (K/Ar возраст 313 млн лет) и биотитом LP-6 (128.1 млн лет), которые использовали в качестве мониторов, заворачивали в алюминиевую фольгу, помещали в кварцевую ампулу и после откачки из нее воздуха запаивали. Затем пробы облучали в кадмированном канале реактора ВВР-К типа в Научно-исследовательском институте ядерной физики (г. Томск). Градиент нейтронного потока не превышал $0.5 \%$ в размере образца. Эксперименты по ступенчатому прогреву проводили в кварцевом реакторе с печью внешнего прогрева. Холостой опыт по определению ${ }^{40} \mathrm{Ar}(10 \mathrm{мин}$ при $1200{ }^{\circ} \mathrm{C}$ ) не превышал $5 \times 10^{-10} \mathrm{HсM}^{3}$. Очистку аргона осуществляли с помощью Ti- и ZrAlSAES-геттеров. Изотопный состав аргона измеряли на масс-спектрометре МИ-1201B. Ошибки измерений соответствуют интервалу $\pm 2 \sigma$. Для коррекции на изотопы ${ }^{36} \mathrm{Ar},{ }^{37} \mathrm{Ar},{ }^{40} \mathrm{Ar}$, полученные при облучении $\mathrm{Ca}, \mathrm{Cl}, \mathrm{K}$, использовали следующие коэффициенты: $\left({ }^{39} \mathrm{Ar} /{ }^{37} \mathrm{Ar}\right) \mathrm{Ca}=0.00073 \pm$ $0.000026,\left({ }^{36} \mathrm{Ar} /{ }^{37} \mathrm{Ar}\right) \mathrm{Ca}=0.00032 \pm 0.000021$, $\left({ }^{40} \mathrm{Ar} /{ }^{39} \mathrm{Ar}\right) \mathrm{K}=0.0641 \pm 0.0001$. Для оценки надежности ${ }^{40} \mathrm{Ar} /{ }^{39} \mathrm{Ar}$ датирования принимались следующие критерии: 1) хорошо выраженное плато не менее чем из трех ступеней (горизонтальный спектр возрастов) с более чем 50 \% выделившегося кумулятивного ${ }^{39} \mathrm{Ar}(\mathrm{CKBO}<2.5)$; 2) конкордантность возрастов плато и изохроны с учетом погрешностей; 4) изохрона пересекает значение отношения ${ }^{40} \mathrm{Ar} /{ }^{36} \mathrm{Ar}$ близко к 295.5. Pacчет и построение графиков для Ar-Ar датирования выполняли в программе Isoplot 3.75 (Ludwig, 2003).

Для оптических методов исследований применяли микроскоп Axioplan Imaging. Состав рудных минералов диагностировали на микроанализатоpe Camebax c использованием энергодисперсионного спектрометра X-Max Oxford и математического обеспечения Aztec, а также на сканирующем электронном микроскопе Jeol JSM-6510LA c энергодисперсионным спектрометром.

\section{ГЕОЛОГИЧЕСКОЕ СТРОЕНИЕ КОНГИНСКОЙ ЗОНЫ}

Конгинская магматическая зона представляет собой линейную структуру протяженностью около 150 км при ширине 15-50 км, образованную сближенными вулканоструктурами и интрузивными телами (рис. 1). Вулканические образования наложены на домеловые комплексы и представлены андезитами, дацитами и риолитами, объединенными в конгинскую свиту (Лычагин и др., 1990; Горячев и др., 2017). Среди образуемых ими структур преобладают интрузивнокупольные поднятия; намного реже встречаются вулканические кальдеры или депрессии. В основании свиты залегают конгломераты и песчаники с отдельными прослоями андезибазальтов и остатками позднеальбской и сеноманской флоры (Лычагин др., 1990). Среди эффузивов преобладают андезиты, реже - базальты и дациты; риолиты отмечаются спорадически. Характерны ассоциирующие с эффузивами многочисленные полого залегающие субвулканические тела (силлы и лакколиты). Петрохимический состав вулканитов характеризуется повышенной калиевой щелочностью (Лычагин и др.., 1990). Интрузии Конгинской зоны объединены в викторинский комплекс (Лычагин и др., 1990) и представлены, в большинстве своем, мелкими (площадь выходов до $10 \mathrm{kм}^{2}$ ) штоками простого (одно- и двухфазного) строения, сложенными преимущественно порфировидными субщелочными породами умеренной кремнекислотности: монцонитами, гранодиоритами, кварцевыми диоритами, граносиенитами. Установлены редкие выходы габбро и гранитов. Изредка породы комплекса слагают относительно крупные (40-90 км²) интрузивные массивы (Ветвистый, Мрачный). Интрузии прорывают и домеловые комплексы, и вулканиты конгинской свиты. Все породы умеренно-щелочные, с калий-натриевым типом щелочности, высокоглиноземистые. По сравнению с кларком они обогащены элементами группы железа (Fe, Cr, Ni, Co, Mn), а также $\mathrm{Ba}, \mathrm{Mo}, \mathrm{As}, \mathrm{W}, \mathrm{Nb}, \mathrm{Zr}$. Обеднение относительно кларка наблюдается для большинства крупноионных литофилов (за исключением Ва), Y и $\mathrm{REE}$. Следует отметить, что ареал развития интрузий викторинского комплекса существенно шире, нежели границы собственно одноименной зоны, и охватывает практически всю центральную и южную части ОМ.

Вулканиты и интрузии Конгинской зоны вмещают многочисленные месторождения и рудопроявления медно-молибден-порфировой, золото-серебряной и серебро-полиметаллической формаций. Их пространственное положение контролируется, в первую очередь, размещением гранитоидных интрузий викторинского комплек- 
Рис. 1. Тектоно-минерагеническая схема Омолонского террейна (по А. М. Гагиевой и И. Л. Жулановой, 2011, с упрощениями и дополнениями): 1 - дорифейский кристаллический фундамент; 2 - рифейскосреднеюрский и верхнеюрскомеловой структурный ярусы; 3-5 вулканогенные пояса (3 - Кедонский, 4 - Охотско-Чукотский и Олойский); 5 - террейны складчатого обрамления (КН - Куларо-Нерский, ВЛ - Вилигинский, ЕP - Еропольский); 6 гранитоиды; 7 - разломы; 8-13 - месторождения и рудопроявления различных формаций: 8 - железистые кварциты, 9 - железорудные скарны, 10 - медно-молибден-порфировая, 11 - серебро-полиметаллическая, 12 - золото-серебряная, 13 - золоторедкометалльная; 14 - границы Эвенского рудного района (Эв); 15 - границы Конгинской зоны (Ко). Звездочками показаны эксплуатируемые $\mathrm{Au}-\mathrm{Ag}$ месторождения Кубака (Кб), Биркачан (Бр), Ольча (Ол). Номерами обозначены месторождения и рудопроявления, упомянутые в статье: 1 - Вечернее, 2 - Хрустальное, 3 - Захаренко, 4 Лабазное, 5 - Вулкан, 6 - Гном, 7 Терминэ, 8 - Упрямое, 9 - Правое Визуальное, 10 - Седое, 11 - Жаркое, 12 - Мрачное, 13 - Хивач, 14 Джелты, 15 - Коаргычан, 16 - Ирбычан, 17 - Невенрекан, 18 - Ороч, 19 - Дручак, 20 - Аура, 21 - Радуга, 22 - Перекатное, 23 - Туромча,

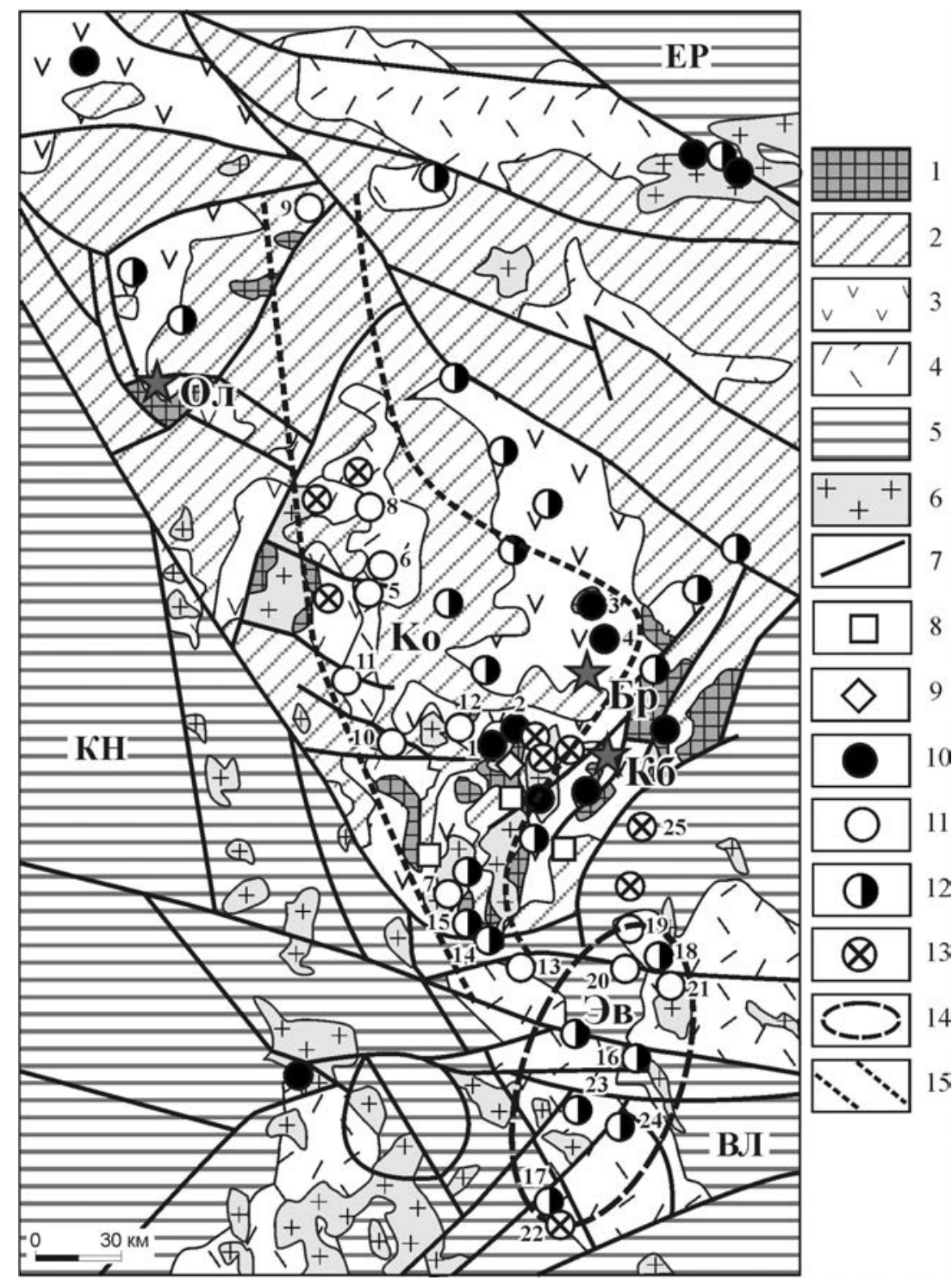
24 - Альдигич, 25 - Горное

Fig. 1. Tectonic and mineragenic scheme of the Omolon terrane (after A. M. Gagiyeva and I. L. Zhulanova, 2011, simplified and amended): 1 - dorifean crystal foundation; 2 - Riphean-Middle Jurassic and Upper Jurassic-Cretaceous structural tiers; 3-5 - volcanic belts (3 - Kedon, 4 - Okhotsk-Chukotka and Oloy); 5 - folded rim terranes (KH - Kularo-Nera, ВЛ - Viliga, EP - Yeropol); 6 - granitoids; 7 - faults; 8-13 - deposits and ore occurrences of different formations (8 - Fe-quartzites, 9 - Fe-skarns, 10 - copper-molybdenum-porphyry, 11 - Ag-polymetallic, 12 Au-Ag, 13 - gold-rare-metallic); 14 - boundaries of the Evensk ore district (Эв); 15 - Kongin zone boundaries (Ко). Asterisks mark working Au-Ag deposits Kubaka (Кб), Birkachan (Бр), Ol'cha (Ол). Numbered are deposits and ore occurrences discussed: 1 - Vecherneye, 2 - Khrustal'noye, 3 - Zakharenko, 4 - Labaznoye, 5 - Vulkan, 6 - Gnom, 7 - Termine, 8 - Upryamoye, 9 - Pravoye Vizual'noye, 10 - Sedoye, 11 - Zharkoye, 12 - Mrachnoye, 13 - Khivatch, 14 - Dzhelty, 15 - Koargychan, 16 - Irbychan, 17 - Nevenrekan, 18 - Oroch, 19 - Druchak, 20 - Aura, 21 - Raduga, 22 - Perekatnoye, 23 - Turomcha, 24 - Al'digitch, 25 - Gornoye

са, а во-вторых - пересечениями дуговых разрывов, ограничивающих интрузивно-купольные поднятия с региональными разломами северозападной и субширотной ориентировки.

\section{РЕЗУЛЬТАТЫ}

Оруденение медно-молибден-порфировой формащии в большинстве случаев непосредственно вмещается гранитоидными интрузиями. На рудопроявлениях Вечернее и Хрустальное (см. рис. 1) минерализация представлена сульфиднокварцевыми штокверками и залежами оруденелых скарнов (Пак, 2002). Выделяются три минеральных парагенезиса: гранат-магнетитовый (скарновый), пирит-арсенопирит-молибденитполисульфидный, золото-серебро-теллуридновисмутовый (Алексеенко и др., 1990; Горячев и др., 2017). Содержания молибдена достига- 
ют $0.2 \%$, меди $-0.5 \%$, серебра - 85 г/т, золота -3.7 г/т. Следует отметить, что мы относим рассматриваемую минерализацию именно к медно-молибден-порфировой формации, а не молибден-порфировой («тип Клаймакс»; Lundington, Plumlee, 2009).

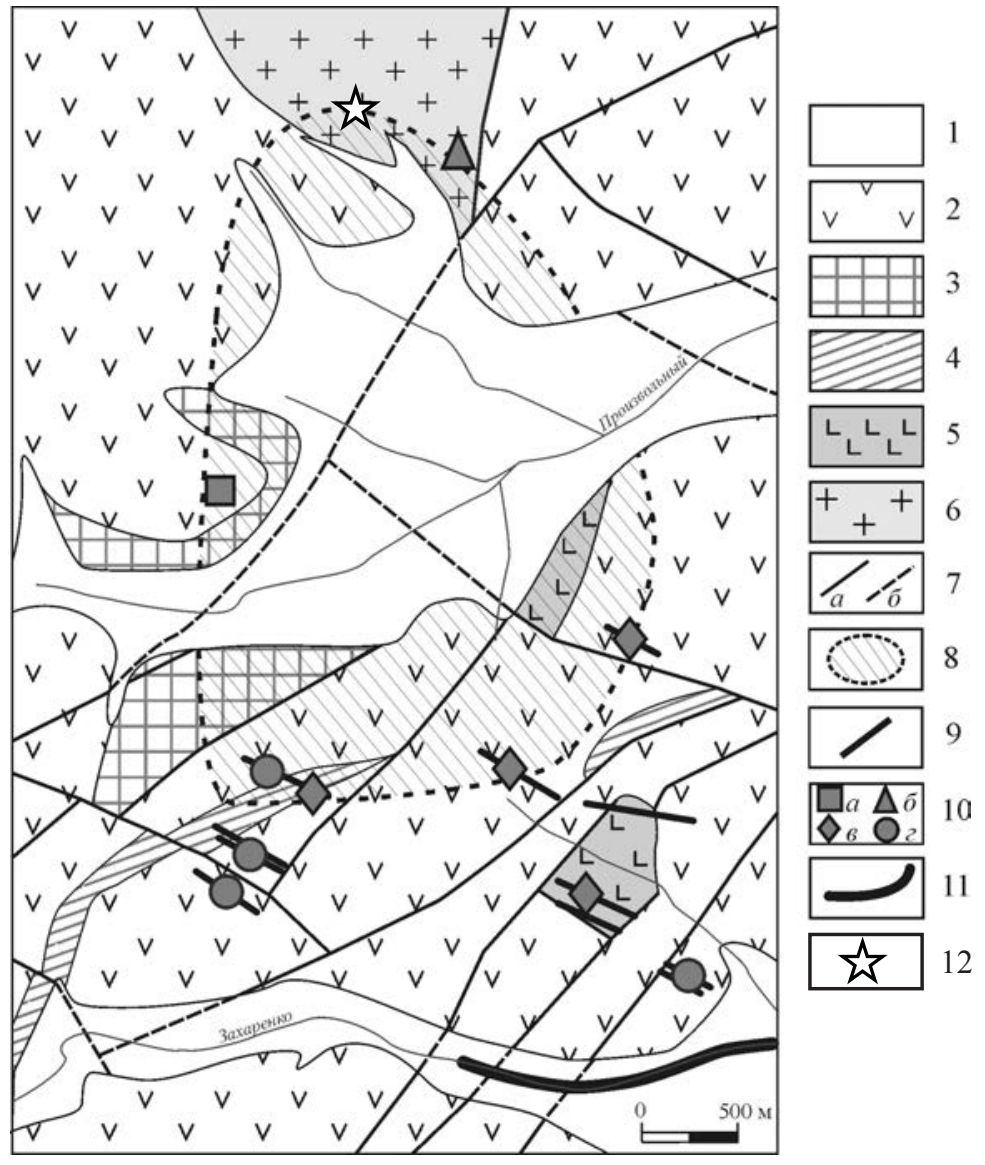

Puc. 2. Схема геологического строения рудопроявления Захаренко (по В. Н. Кудиенко, 2002 г., с изменениями и дополнениями): 1 - рыхлые четвертичные отложения; 2 - туфы и игнимбриты риодацитов кедонской серии; 3 - архейские гнейсы; 4 - экструзии и субвулканические тела риолитов кедонского комплекса; 5 - субвулканические тела диорит-порфиритов; 6 - гранодиориты; 7 - разломы, достоверно установленные $(a)$ и предполагаемые (б); 8 - сульфидно-кварцевый штокверк; 9 - карбонат-кварцевые жилы; 10 - пункты минерализации молибдена $(a)$, меди (б), свинца (в), золота (2); 11 - россыпь золота; 12 - проба ${ }^{39} \mathrm{Ar} /{ }^{40} \mathrm{Ar}$ датирования (рис. 3)

Fig. 2. Geological scheme of the Zakharenko ore field (after V. N. Kudienko, 2002, altered and amended): 1 - Quaternary talus rocks; 2 - rhyodacite ignimbrites and tuffs of the Kedon formation; 3 - Archean gneisses; 4 - Kedon rhyolite extrusions and subvolcanic bodies; 5 - Cretaceous diorite-porphyry subvolcanic bodies; 6 - Cretaceous granodiorites; 7 - faults proved $(a)$, assumed $(\sigma) ; 8$ - sulfide-quartz stockwork; 9 - carbonate-quartz lodes; 10 - mineralization points of $\operatorname{Mo}(a)$, $\mathrm{Cu}$ (б), $\mathrm{Pb}($ (8), $\mathrm{Au}$ (2); 11 - gold placer; 12 sample ${ }^{39} \mathrm{Ar} /{ }^{40} \mathrm{Ar}$ dating (Fig. 3)

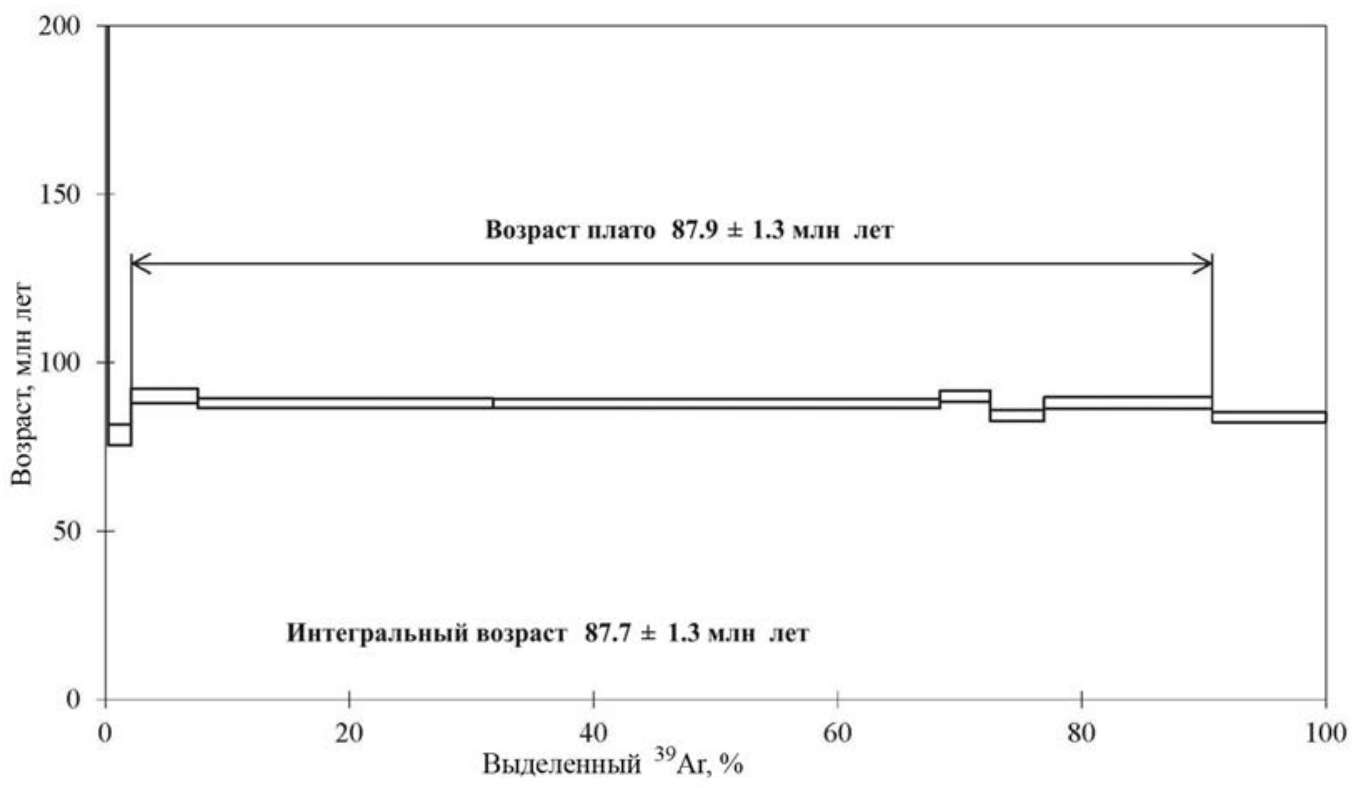

Puc. 3. Результаты ${ }^{39} \mathrm{Ar} /{ }^{40} \mathrm{Ar}$ датирования серицита из филлизитов Захаренковского рудного поля

Fig. 3. Results of ${ }^{39} \mathrm{Ar} /{ }^{40} \mathrm{Ar}$ dating of sericite from the Zakharenko ore field phyllisites 

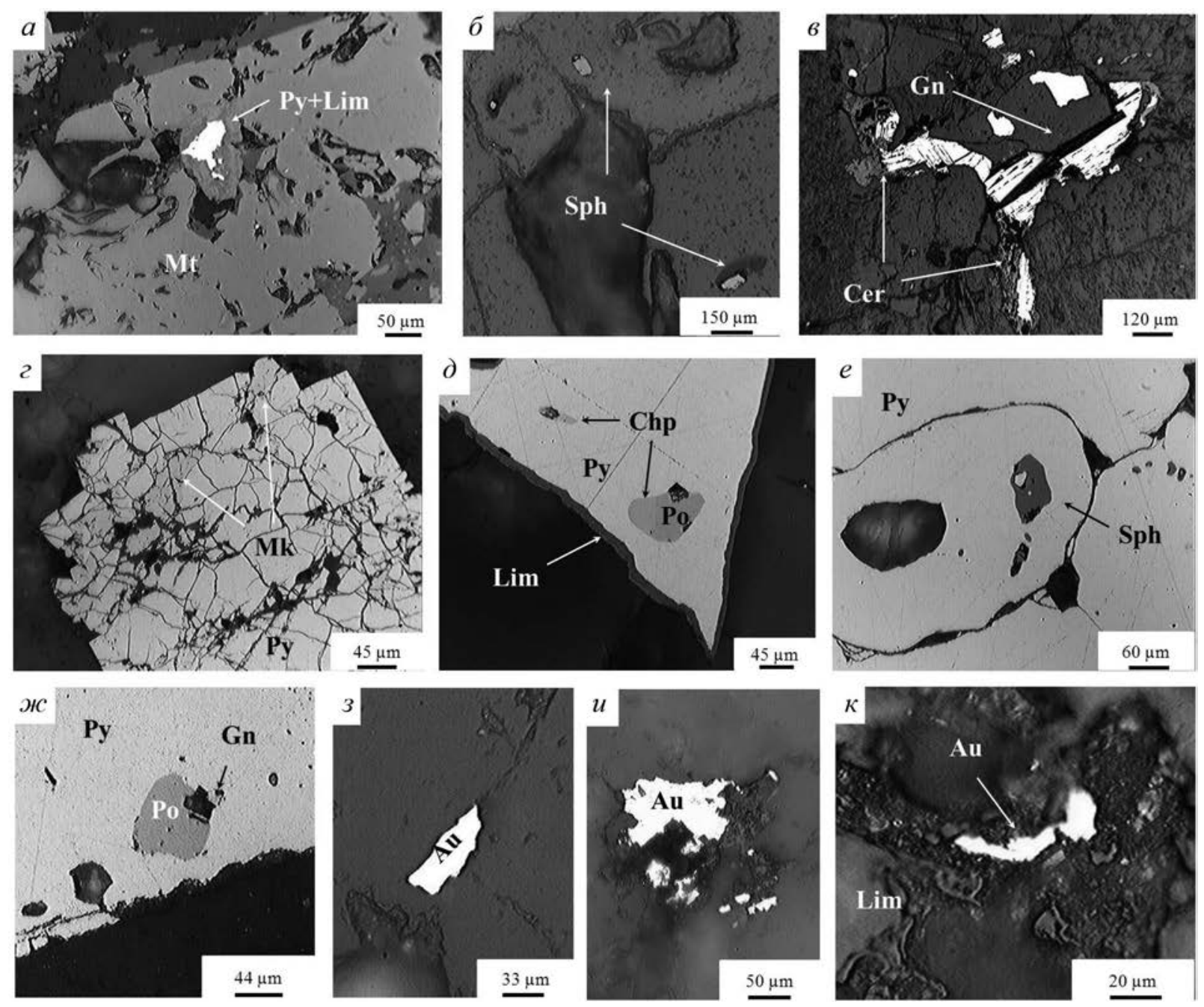

Рис. 4. Минералогия золото-серебро-полиметаллических жил Захаренковского рудного поля: $a-$ включение пирита в магнетите; пирит по периферии замещен лимонитом; $\sigma$ - микровключения сфалерита в кварце; в - развитие церуссита по периферии галенита; 2 - полиморфное развитие марказита по пириту; $\partial$ - пирротин в ассоциации с халькопиритом образует включения в пирите; $e-$ включения сфалерита в пирите; ж- галенит и пирротин выполняют пустоты в пирите; з - включение самородного золота в кварце; $u$ - ксеноморфное обособление самородного золота в кварце; золото корродируется лимонитом; $к-$ включение самородного золота в лимонитизированном пирите

Fig. 4. Mineralogy of gold-silver-polymetallic lodes at the Zakharenko ore field: $a$-pyrite inclusion in magnetite; peripheral pyrite replaced by limonite; $\sigma$ - microinclusions of sphalerite in quartz; 6 - development of zerussite at the galena periphery; 2 - polymorphic development of marcasite on pyrite; $\partial$ - inclusions of pyrrhotite and chalcopyrite in pyrite; $e$ - sphalerite inclusions in pyrite; $\mathscr{H}$ - galena and pyrrhotite filling cavities in pyrite; $3-$ native gold in quartz; $u$ - xenomorphic isolation of native gold corroded by limonite; $\kappa$ - native gold inclusion in limonitizied pyrite

В пользу этого свидетельствуют монцонитгранодиоритовый состав связанных с оруденением гранитоидов (рис. 2), относящихся к І-типу (a не S- и A-, как для собственно молибденпорфировых), и ассоциация с золото-серебряной и полиметаллической (а не олово-вольфрамовой) минерализацией. Высокие концентрации молибдена, как и флюорита, отражают сиалический состав рудовмещающих комплексов кристаллического фундамента Омолонского террейна.

С медно-молибденовым рудопроявлением Хрустальное ассоциируют железорудные скарны
(Фадеев, 1974). Они развиты по рифейским карбонатным отложениям и представлены залежами гранат-пироксен-магнетитового состава с содержаниями железа 20-58 \% и золота до 0.3 г/т.

На периферии медно-молибденовые штокверки сменяются жилами и прожилками с золотосеребро-полиметаллической минерализацией. Примером является Захаренковское рудное поле (см. рис. 1 и 2). Оно приурочено к интрузивнокупольному поднятию, в ядре которого обнажен шток викторинского интрузивного комплекса площадью 3.5 км². Он имеет двухфазное стро- 
Таблииа 1. Результаты микрозондового анализа сульфидов Захаренковского рудного поля Table 1. Results of microprobe analysis on the Zakharenko ore field sulfides

\begin{tabular}{|c|c|c|c|c|c|c|c|c|c|c|c|c|}
\hline № П/П & Номер образца & Сумма & \multicolumn{5}{|c|}{ Весовые концентрации, \% } & \multicolumn{5}{|c|}{ Формульные коэффициенты } \\
\hline \multicolumn{13}{|c|}{ Галенит $-\mathrm{Pb}_{1.04} \mathrm{~S}_{0.96}$} \\
\hline & & & $\mathrm{Pb}$ & \multicolumn{3}{|c|}{$\mathrm{S}$} & $\mathrm{Fe}$ & & $\mathrm{Pb}$ & & $\mathrm{S}$ & $\mathrm{Fe}$ \\
\hline 1 & 45 & 100.00 & 70.75 & \multicolumn{3}{|c|}{29.25} & 0.00 & & 0.54 & & 1.46 & 0.00 \\
\hline 2 & 41 & 100.24 & 87.45 & \multicolumn{3}{|c|}{12.79} & 0.00 & & 1.03 & & 0.97 & 0.00 \\
\hline 3 & 41 & 78.55 & 69 & \multicolumn{3}{|c|}{9.55} & 0.00 & & 1.06 & & 0.94 & 0.00 \\
\hline 4 & 41 & 100.25 & 87.82 & \multicolumn{3}{|c|}{12.43} & 0.00 & & 1.04 & & 0.96 & 0.00 \\
\hline 5 & 41 & 99.68 & 87.41 & \multicolumn{3}{|c|}{12.27} & 0.00 & & 1.05 & & 0.95 & 0.00 \\
\hline 6 & 41 & 100.00 & 87.29 & \multicolumn{3}{|c|}{12.71} & 0.00 & & 1.03 & & 0.97 & 0.00 \\
\hline \multicolumn{13}{|c|}{ Галенит - $\left(\mathrm{Pb}_{0.79} \mathrm{Fe}_{0.22}\right)_{1.01} \mathrm{~S}_{0.98}$} \\
\hline 7 & 41 & 84.83 & 71.43 & \multicolumn{3}{|c|}{10.43} & 2.97 & & 0.95 & & 0.9 & 0.15 \\
\hline 8 & 44 & 100.00 & 71.98 & \multicolumn{3}{|c|}{18.78} & 9.24 & & 0.63 & & 1.07 & 0.30 \\
\hline \multicolumn{13}{|c|}{ Пирротин $-\mathrm{Fe}_{7.08} \mathrm{~S}_{7.92}$} \\
\hline & & & \multirow{2}{*}{\multicolumn{3}{|c|}{$\begin{array}{c}\mathrm{Fe} \\
59.92\end{array}$}} & \multicolumn{2}{|c|}{$\mathrm{S}$} & \multirow{2}{*}{\multicolumn{3}{|c|}{$\begin{array}{c}\mathrm{Fe} \\
7.06\end{array}$}} & \multicolumn{2}{|c|}{$\mathrm{S}$} \\
\hline 9 & 44 & 98.57 & & & & \multirow{2}{*}{\multicolumn{2}{|c|}{$\begin{array}{l}38.65 \\
38.99\end{array}$}} & & & & \multicolumn{2}{|c|}{7.94} \\
\hline 10 & 44 & 99.93 & \multicolumn{3}{|c|}{60.94} & & & \multicolumn{2}{|r|}{7.09} & \multicolumn{3}{|c|}{7.91} \\
\hline \multicolumn{13}{|c|}{ Пирит $-\mathrm{Fe}_{1.00} \mathrm{~S}_{2.00}$} \\
\hline & & & \multicolumn{3}{|c|}{$\mathrm{Fe}$} & $\mathrm{S}$ & & & $\mathrm{Fe}$ & & & \\
\hline 11 & 45 & 100.00 & & 6.17 & & 53. & & & 0.99 & & & \\
\hline 12 & 45 & 100.00 & & 6.12 & & 53. & & & 0.99 & & & \\
\hline 13 & 44 & 100.00 & & 6.65 & & 53. & & & 1.00 & & & \\
\hline 14 & 41 & 99.34 & & 6.81 & & 52. & & & 1.02 & & & \\
\hline 15 & 41 & 100.00 & & 6.71 & & 53.2 & & & 1.00 & & & \\
\hline & & & & Кальког & пирит - & $\mathrm{Cu}_{0.9}$ & $\mathrm{Fe}_{1.05} \mathrm{~S}_{1}$ & & & & & \\
\hline & & & $\mathrm{Cu}$ & & $\mathrm{Fe}$ & & $\mathrm{S}$ & & $\mathrm{Cu}$ & & $\mathrm{Fe}$ & $\mathrm{S}$ \\
\hline 19 & 44 & 100.00 & 33.61 & & 31.82 & & 34.57 & & 0.97 & & 1.05 & 1.98 \\
\hline & & & $\mathrm{C} \phi$ & ллерит - & $-\left(\mathrm{Zn}_{0}\right.$ & $\mathrm{Fe}_{0.2} \mathrm{~N}$ & $\left(\mathrm{n}_{0.03}\right)_{1.0}$ & $\mathrm{~S}_{0.99}$ & & & & \\
\hline & & & $\mathrm{Zn}$ & $\mathrm{Fe}$ & $\mathrm{Mn}$ & $\mathrm{Cd}$ & $\mathrm{S}$ & $\mathrm{Zn}$ & $\mathrm{Fe}$ & $\mathrm{Mn}$ & $\mathrm{Cd}$ & $\mathrm{S}$ \\
\hline 20 & 41 & 100.01 & 54.20 & 11.24 & 1.19 & 0.23 & 33.15 & 0.79 & 0.19 & \begin{tabular}{l|l}
0.02 \\
\end{tabular} & 0.00 & 0.99 \\
\hline 21 & 41 & 100.00 & 53.20 & 11.56 & 1.36 & 0.47 & 33.41 & 0.78 & 0.20 & 0.02 & 0.00 & 1.00 \\
\hline 22 & 41 & 100.00 & 52.67 & \begin{tabular}{|l|}
11.44 \\
\end{tabular} & 1.94 & 0.45 & 33.50 & 0.77 & 0.20 & 0.03 & 0.00 & 1.00 \\
\hline 23 & 41 & 100.00 & 52.91 & 11.56 & 1.75 & 0.55 & 33.23 & 0.77 & 0.20 & 0.03 & 0.00 & 0.99 \\
\hline
\end{tabular}

Примечание. Анализ выполнен на сканирующем электронном микроскопе Jeol JSM-6510LA с энергодисперсионным спектрометром, СПб., 2019. Аналитик О. Л. Галанкина.

Таблица 2. Результаты микрозондового анализа петровскаита и самородного золота Захаренковского рудного поля

Table 2. Results of microprobe analysis on petrovskaite and native gold from the Zakharenko ore field

\begin{tabular}{|c|c|c|c|c|c|c|c|c|}
\hline \multirow{2}{*}{ № п/п } & \multirow{2}{*}{ Номер образца } & \multirow{2}{*}{ Сумма } & \multicolumn{3}{|c|}{ Весовые концентрации, \% } & \multicolumn{3}{|c|}{ Формульные коэффициенты } \\
\hline & & & $\mathrm{Au}$ & $\mathrm{Ag}$ & $\mathrm{S}$ & $\mathrm{Au}$ & $\mathrm{Ag}$ & $\mathrm{S}$ \\
\hline \multicolumn{9}{|c|}{ Петровскаит $-\mathrm{Au}_{0.99} \mathrm{Ag}_{0.96} \mathrm{~S}_{1.05}$} \\
\hline 1 & 33 & 100.01 & 57.62 & 31.91 & 10.48 & 0.96 & 0.97 & 1.07 \\
\hline 2 & 33 & 100.01 & 59.82 & 30.29 & 9.90 & 1.02 & 0.94 & 1.04 \\
\hline \multicolumn{9}{|c|}{ Средняя пробность - 668.1 \%о } \\
\hline 3 & 33 & 100.00 & 61.38 & 38.62 & 0.00 & 0.93 & 1.07 & 0.00 \\
\hline 4 & 33 & 100.00 & 61.51 & 38.49 & 0.00 & 0.93 & 1.07 & 0.00 \\
\hline 5 & 33 & 100.00 & 62.29 & 37.71 & 0.00 & 0.95 & 1.05 & 0.00 \\
\hline 6 & 33 & 100.00 & 65.53 & 34.47 & 0.00 & 1.02 & 0.98 & 0.00 \\
\hline 7 & 33 & 100.00 & 66.59 & 33.41 & 0.00 & 1.04 & 0.96 & 0.00 \\
\hline 8 & 32 & 100.00 & 66.71 & 33.29 & 0.00 & 1.05 & 0.95 & 0.00 \\
\hline 9 & 32 & 100.00 & 67.11 & 32.89 & 0.00 & 1.06 & 0.94 & 0.00 \\
\hline 10 & 33 & 100.00 & 67.38 & 32.62 & 0.00 & 1.06 & 0.94 & 0.00 \\
\hline 11 & 33 & 100.00 & 67.70 & 32.30 & 0.00 & 1.07 & 0.93 & 0.00 \\
\hline 12 & 33 & 100.00 & 70.64 & 29.36 & 0.00 & 1.14 & 0.86 & 0.00 \\
\hline 13 & 32 & 100.00 & 71.61 & 28.39 & 0.00 & 1.16 & 0.84 & 0.00 \\
\hline 14 & 32 & 100.00 & 73.23 & 26.77 & 0.00 & 1.20 & 0.80 & 0.00 \\
\hline \multicolumn{9}{|c|}{ Высокопробная кайма - 953.4 \%о } \\
\hline 15 & 33 & 100.00 & 95.34 & 4.66 & 0.00 & 1.84 & 0.16 & 0.00 \\
\hline
\end{tabular}

Примечание. Анализ выполнен на сканирующем электронном микроскопе Jeol JSM-6510LA с энергодисперсионным спектрометром, СПб., 2019. Аналитик О. Л. Галанкина 
ение и сложен габбро-диоритами, диоритами, монцодиоритами, диорит-порфиритами. U-Pb возраст кристаллизации циркона из монцодиоритов (TIMS) составил $86.4 \pm 0.3$ млн лет (Глухов и др., 2021). Интрузия прорывает туфы и игнимбриты риолитов кедонской серии среднего - позднего девона. Они изменены до филлизитов пирит-серицит-кварцевого состава и вмещают сульфидно-кварцевые штокверки с пиритом, пирротином, халькопиритом, сфалеритом и молибденитом. Содержания Мо и Сu в штокверках до $0.03 \%, \mathrm{~Pb}$ - до $0.06 \%, \mathrm{Zn}$ - до $0.04 \%$; геохимический спектр прожилково-вкрапленной минерализации Мo-Ag-Pb-Cu-Zn-Ag. По серициту из филлизитов получена $\mathrm{Ar}-\mathrm{Ar}$ датировка $87.9 \pm 1.3$ млн лет (рис. 3), согласующаяся, с учетом погрешности, с U-Pb возрастом монцодиоритов. На удалении от них развиты рудоносные кварцевые жилы и прожилки с золото-сереброполиметаллической минерализацией. Содержания золота в них до 20 г/т, серебра - до 88 г/т, свинца - более $1 \%$; геохимический спектр жил Au-Pb-Ag-(W, Mo)-As. Жилы и прожилки сложены среднезернистым друзовидным и полупрозрачным кварцем.

Основная рудная минерализация представлена пиритом, сфалеритом, галенитом, халькопиритом, пирротином, самородным золотом и петровскаитом (рис. 4). Пирит содержит редкую вкрапленность пирротина, галенита, сфалерита, халькопирита и самородного золота. Пирротин отлагается в виде ксеноморфных включений в крупнокристаллическом пирите. Встречается в ассоциации с халькопиритом и галенитом. Полисульфиды установлены как в свободном состоянии, так и в срастании с пиритом и пирротином, а также формируют включения в них. При этом в сфалерите установлены высокие концентрации $\mathrm{Fe}, \mathrm{Mn}$ и $\mathrm{Cd}$, а в галените - примесь $\mathrm{Fe}$ (табл. 1). Самородное золото (электрум) образует ксеноморфные включения в пирите и кварце, нередко со следами кристаллической огранки. Размер золотин от 0.008 до 0.11 мм. Пробность золота 613 732 \% (табл. 2). Отдельные частицы имеют высокопробные каймы или оторочку петровскаита. В жилах выделены две рудные минеральные ассоциации: полисульфидная (пирит, пирротин, халькопирит, сфалерит, галенит) и золото-серебряная (электрум, петровскаит). Руды характеризуются относительно утяжеленным изотопным составом сульфидной серы - до $+4.7 \% \delta^{34} \mathrm{~S}$ (VCDT).

На Лабазном рудном поле (рис. 5) слабо вскрытый эрозией шток кварцевых сиенитов и монцодиоритов викторинского комплекса сопровождается ореолом серицит-кварцевых филлизитов с прожилками и вкрапленностью пирита, халькопирита, молибденита. Они содержат Мо и $\mathrm{Zn}$ - до 0.1 \%, Ag - до 1 г/т, $\mathrm{Au}-$ до 0.3 г/т. Геохимический спектр прожилкововкрапленной минерализации $\mathrm{Mo}-\mathrm{Zn}-\mathrm{Au}-\mathrm{Pb}-\mathrm{Ag}$. На удалении обособляются редкие маломощные (до 0.3 м) сульфидно-кварцевые жилы, которые, по данным В. Н. Панькова (1990г.), содержат $\mathrm{Au}$ - до 22 г/т, Ag - до 627 г/т, $\mathrm{Pb}$ и $\mathrm{Zb}$ - до $1 \%$.
Рис. 5. Схема геологического строения рудопроявления Лабазное (по В. Н. Панькову, 1990 г., с упрощениями и дополнениями): 1 - рыхлые четвертичные аллювиальные отложения; 2 - игнимбриты и туфы риодацитов кедонской серии девона; 3 - субвулканические тела риолитов кедонского комплекса девона; 4 - интрузии диоритов викторинского комплекса; 5 - дайки меловых риолитов и базальтов; 6 - сульфидно-кварцевый штокверк; 7 - разломы установленные и предполагаемые; 8 - пункты минерализации золота и серебра

Fig. 5. Geological scheme of the Labaznoye ore field (after V. N. Pan'kov, 1990, simplified and amended): 1 - soft Quaternary alluvial deposits; 2 - rhyodacite ignimbrites and tuffs of the Devonian Kedon formation; 3 rhyolite subvolcanic bodies of the Devonian Kedon complex; 4 - intrusions of Cretaceous diorites (Victorinskiy complex); 5 - dykes of Cretaceous rhyolites and basalts; 6 - sulfidequartz stockwork; 7 - faults proved, assumed; 8 - mineralization points of $\mathrm{Au}$ and $\mathrm{Ag}$

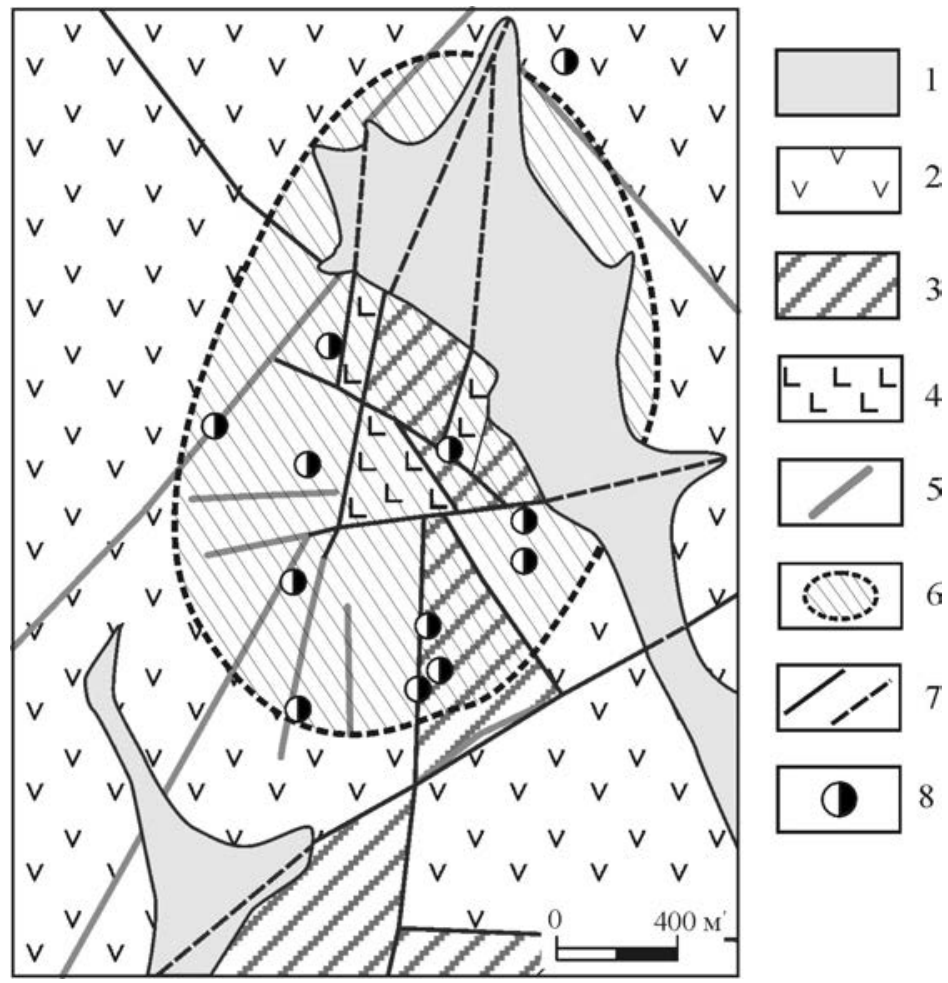



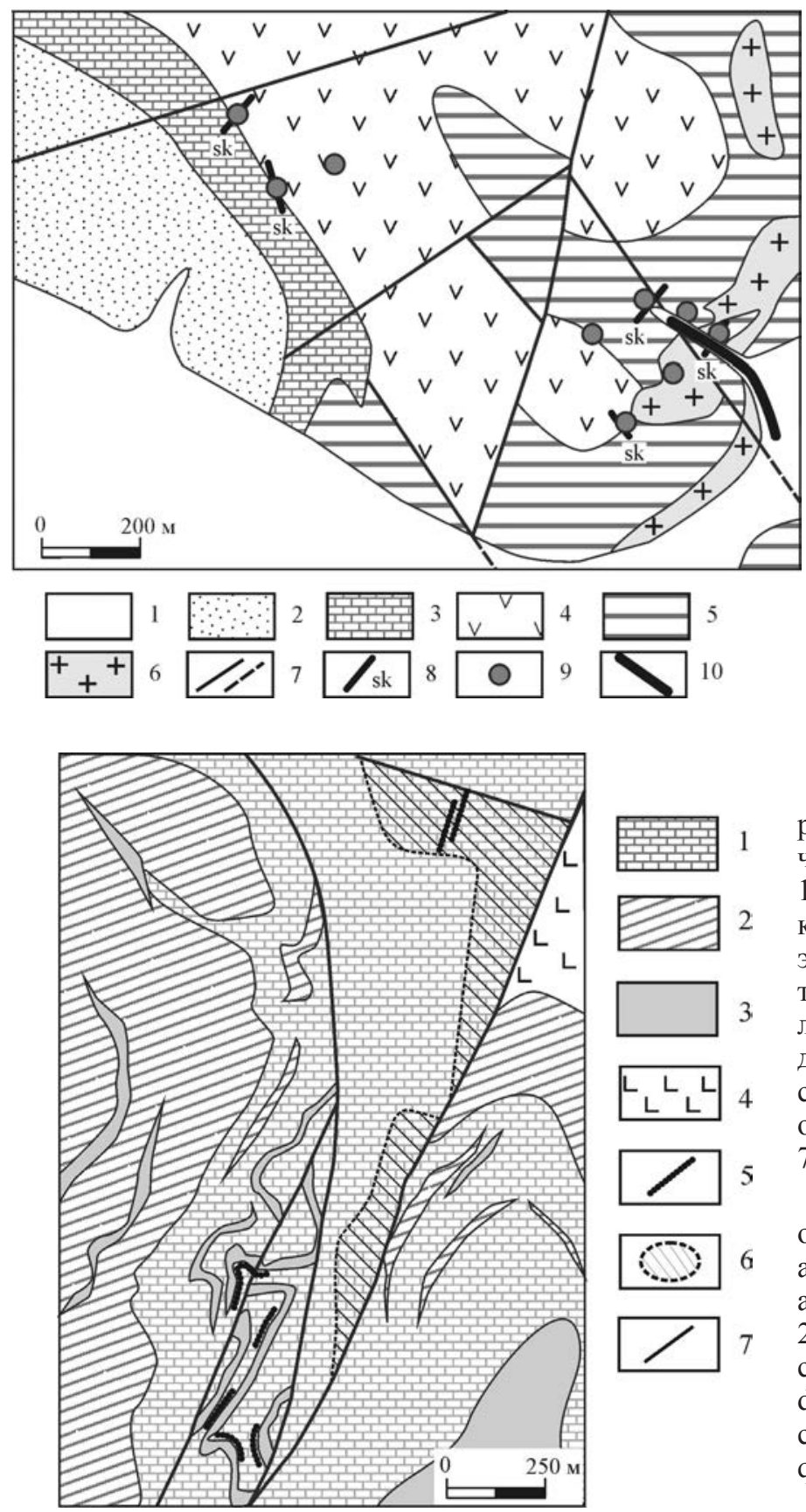

Захаренковское и Лабазное рудные поля по геологической позиции и составу руд относятся к полнопроявленной порфирово-эпитермальной рудной системе (Коваленкер и др., 2006), на нижних уровнях которой развита штокверковая медно-молибден-порфировая минерализация, а на верхних - жильная золото-сереброполиметаллическая.

Рудопроявления серебро-полиметаллической формации представлены сульфидно-карбонатными жилами и прожилковыми зонами (Вулкан, Гном, Терминэ, Упрямое, Правое Визуальное), оруденелыми скарнами (Седое, Жаркое, Мрачное, Хивач). Рудопроявление Седое (см. рис. $1 ; 6)$ локализовано в интрузивно-купольной структуре,
Рuc. 6. Схема геологического строения рудопроявления Седое (по А. Г. Егорову, 1989 г., с упрощениями и дополнениями): 1 - рыхлые четвертичные аллювиальные отложения; 2 - аргиллиты и алевролиты триаса; 3 - пермские известняки; 4 - игнимбриты и туфы риодацитов кедонской серии девона; 5 - известняки ордовика; 6 - гранодиориты викторинского комплекса; 7 - разломы достоверные и предполагаемые; 8 - скарны; 9 - пункты минерализации $\mathrm{Ag}, \mathrm{Pb}, \mathrm{Zn} ; 10$ россыпь самородного серебра

Fig. 6. Geological scheme of the Sedoye ore occurrence (after A. G. Egorov, 1989, simplified and amended): 1 - soft Quaternary alluvial deposits; 2 - Triassic argillites and aleurolites; 3 - Permian limestones; 4 -rhyodacite ignimbrites and tuffs of the Devonian Kedon formation; 5 - Ordovician limestones; 6 - Victorinsky complex granodiorites; 7 - faults proved, ased; 8 - skarns; 9 - mineralization points of $\mathrm{Ag}, \mathrm{Pb}, \mathrm{Zn} ; 10$ - native Ag placer

Puc. 7. Схема геологического строения рудопроявления Джелты (по В. Н. Лазовичу, 1994 г., с изменениями и дополнениями): 1 - вулканогенно-терригенные и терригеннокарбонатные осадочные породы перми; 2 экструзии трахидацитов девонского возраста; 3 - субвулканические тела риолитов мелового возраста; 4 - субвулканические тела диорит-порфиритов мелового возраста; 5 сульфидно-карбонат-кварцевые жилы; 6 - ореолы гидрослюдисто-кварцевых метасоматитов; 7 - разломы

Fig. 7. Geological scheme of the Dzhelty ore occurrence (after V. N. Lazovich, 1994, altered and amended): 1 - Permian volcanic-terrigenous and terrigenous-carbonate sedimentary rocks; 2 - Devonian trachydacite extrusions; 3 - Cretaceous rhyolite subvolcanic bodies; 4 - Cretaceous diorite-porphyry subvolcanic bodies; 5 - sulfidecarbonate-quartz lodes; 6 - aureoles of hydromicaquartz alterations; 7 - faults

которая сложена терригенно-карбонатными породами ордовика, перми и триаса, прорванными гранодиорит-порфирами с U-Pb возрастом по циркону (TIMS) $86.4 \pm 0.4$ млн лет (Глухов и др., 2021). Оруденение представлено кварц-сульфидно-карбонатными прожилками, рассекающими гранатпироксеновые скарны. Рудные минералы: пирит, сфалерит, галенит, халькопирит, стефанит, прустит, пираргирит, самородное серебро, а также, редко - арсенопирит, леллингит, глаукодот, кобальтин, алтаит, гессит, теллуровисмутит, тетрадимит (Савва, 2019). Содержания золота до 8 г/т, серебра - до 197 г/т, свинца и цинка - до 1 \%; геохимический спектр минерализации $\mathrm{Pb}-\mathrm{Ag}-\mathrm{Zn}-\mathrm{As}-\mathrm{Bi}$ W-Sb-Au-Cu-Mn. На рудопроявлениях Вулкан, 
Гном, Терминэ сульфидно-карбонат-кварцевые прожилки с серебро-полиметаллической минерализацией рассекают пропилитизированные эффузивы породы кедонской серии, а также гранитоиды викторинского комплекса. Содержания серебра в рудах достигают 700 г/т, золота - 2 г/т, свинца и цинка - более 10 \%, марганца - $1 \%$. Геохимический спектр $\mathrm{Pb}-\mathrm{Ag}-\mathrm{Zn}-(\mathrm{Au}, \mathrm{As}, \mathrm{Cu})-\mathrm{Mn}$. Иногда серебросодержащие жилы и прожилки являются коренным источником мелких аллювиальных россыпей самородного серебра (Седое, Правое Визуальное; Показаньев и др., 1980; Павлов и др., 1986).
Определенной спецификой характеризуется золото-серебряное оруденение Конгинской зоны. Рудопроявление Джелты (рис. 7), приуроченное к силлам диорит-порфиритов викторинского комплекса, по химическому составу соответствующих кварцевым монцодиоритам. Рудные тела представлены жильно-прожилковыми зонами мощностью от 2 до 20 м. Жилы и прожилки сложены мелко- и скрытокристаллическим кварцем, карбонатом и баритом. Рудные минералы представлены пиритом, халькопиритом, галенитом, сфалеритом, блеклой рудой и электрумом (рис. 8). Пирит срастается с галенитом
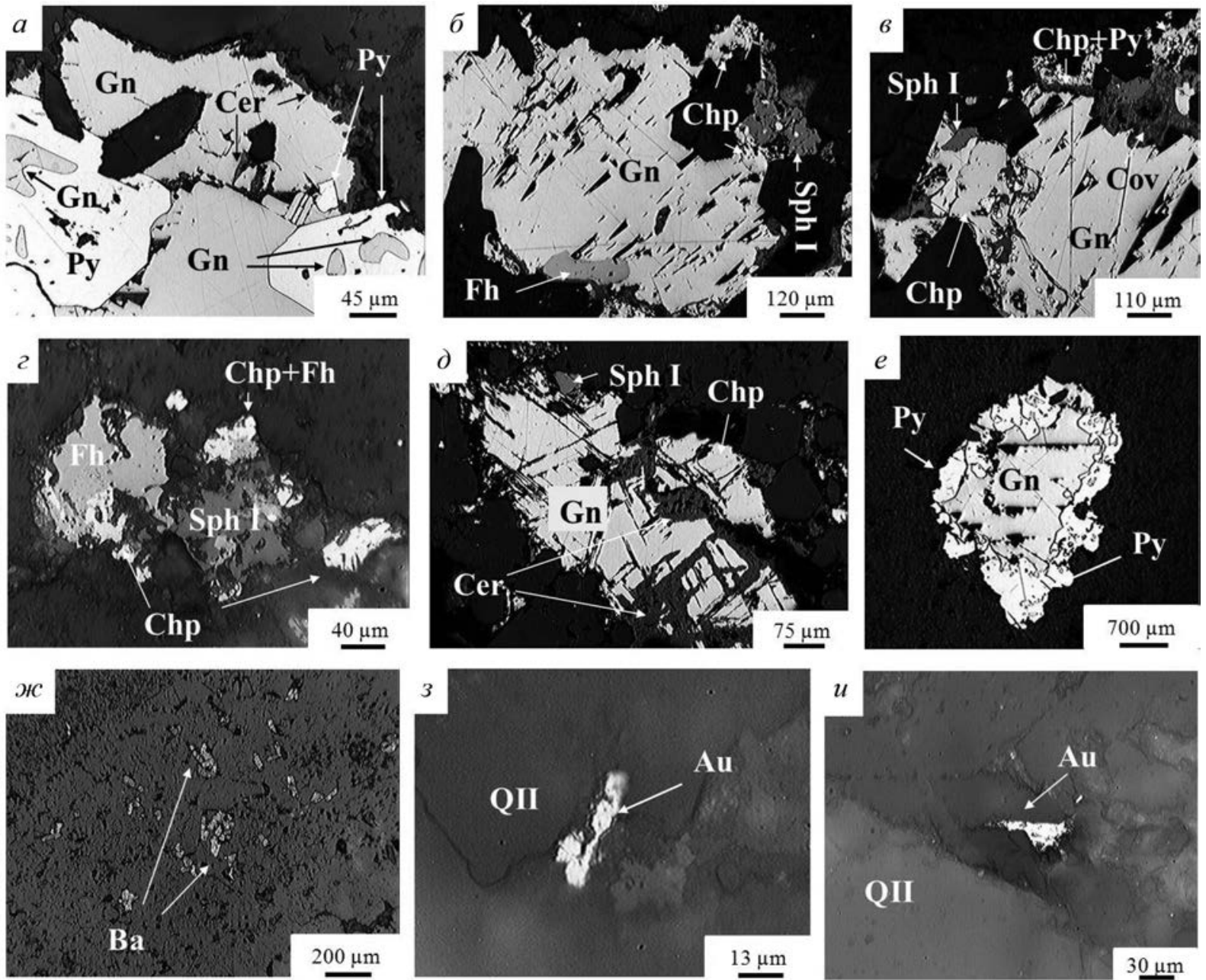

Рис. 8. Минералогия золото-серебро-полиметаллических жил рудопроявления Джелты: $a$ - пирит в срастании с галенитом; по периферии галенита развивается церуссит; $\sigma$ - срастание галенита, халькопирита и сфалерита-I в галените с включением блеклой руды; в - ассоциация сфалерита-I, галенита и халькопирита; халькопирит содержит обломки раннего пирита; на контакте галенита со сфалеритом и халькопиритом развивается ковеллин; 2 - ассоциация халькопирита, сфалерита-І и блеклой руды; $\partial$ - обособления галенита, халькопирита и сфалерита; галенит по периферии и по спайности замещен церусситом; $e$ - галенит, заполняющий пустоты в пирите; ж- игольчатые обособления барита; з, $u$ - микровключения самородного золота в кварце-ІІ

Fig. 8. Mineralogy of gold-silver-polymetallic quartz lodes of the Dzhelty ore occurence: $a$-intergrowth of pyrite and galena; zerussite developing at the galena periphery; $\sigma$-intergrowth of galena, chalcopyrite, and sphalerite-I with an inclusion of tetrahedrite; $b$ - paragenesis of sphalerite-I, galena, and chalcopyrite; chalcopyrite containing earlier pyrite fragments ; covellite developing at the contact of galena with sphalerite and chalcopyrite; 2 - association of chalcopyrite, sphalerite-I, and tetrahedrite; $\partial$ - isolations of galena, chalcopyrite, and sphalerite; galena replaced by zerussite at the periphery; $e$-galena, fillingcavities in pyrite; $\nVdash$ - spicular isolations of barite; $3, u$ - microinclusions of native gold in quartz-II 
и сфалеритом, содержит микровключения галенита и блеклой руды. Полисульфиды отлагаются как в свободном состоянии, так и в срастании между собой. При исследовании на микроанализаторе установлено, что сфалерит характеризуется низкими примесями $\mathrm{Fe}$ и $\mathrm{Cd}$ (табл. 3). В галените обнаружена микропримесь Ag, а блеклые руды по своему составу соответствуют Ag-Fe- и Ag- Znтетраэдритам. Кроме того, в ассоциации с блеклой рудой обнаружена ртутьсодержащая минеральная фаза, химический состав которой $-\mathrm{Ag}-41.54 \%$, $\mathrm{Hg}-30.11 \%, \mathrm{Zn}-11.37 \%, \mathrm{~S}-16.87 \%$. Самородное золото (электрум) образует единичные ксеноморфные включения в кварце, размером от 0.03 0.09 мм. Пробность 487-550 \%о (см. табл. 3).

В рудах установлены две минеральные ассоциации: 1) пирит-карбонат-барит-кварцевая, 2) золото-блеклорудно-полисульфидная. Содержания золота до 9.7 г/т, серебра - до 1913 г/т. Характерны высокие, иногда превышающие $1 \%$, концентрации свинца и цинка. Геохимический спектр оруденения Ag-Pb-Au-As-Sb-Zn-Mo. Рyды характеризуются близким к метеоритному, изотопным составом сульфидной серы - с $+0.3 \% \mathrm{~d}^{34} \mathrm{~S}$ (VCDT). Близкое геологическое строение и состав руд имеет рудопроявление Коаргычан. По современной классификации (Sillitoe, Hedenquist, 2003) данные объекты относятся к среднесульфидированному типу эпитермальной минерализации («Intermediate Sulfidation» IS). Главные отличительные черты данного типа: ассоциация с вулканическими и субвулканическими телами кислого и среднего состава, широкое развитие карбонатов и $\mathrm{Cu}-\mathrm{Pb}-\mathrm{Zb}$ минералов в рудах, низкое отношение $\mathrm{Au} / \mathrm{Ag}$ (1:10-1:100). В 6 км к югу располагается Хивачское рудное поле с серебро-полиметаллической минерализацией в жилах и залежах скарнов (Болдырев, Яранцева, 1991). Можно предположить, что рудопроявление Джелты генетически с ним связано, являясь дистальной, низкотемпературной частью данной гранитоидной рудной системы.

Таблица 3. Результаты микрозондового анализа сульфидов и самородного золота рудопроявления Джелты

Table 3. Results of microprobe analysis on sulfides and native gold from the Dzhelty ore occurrence

\begin{tabular}{|c|c|c|c|c|c|c|c|c|c|c|c|c|c|c|c|c|}
\hline № $\Pi / \Pi$ & № обр. & Сумма & \multicolumn{7}{|c|}{ Весовые концентрации, \% } & \multicolumn{7}{|c|}{ Формульные коэффициенты } \\
\hline \multicolumn{17}{|c|}{ Пирит-I $-\mathrm{Fe}_{1.00} \mathrm{~S}_{1.99}$} \\
\hline & & & \multicolumn{2}{|c|}{$\mathrm{Fe}$} & \multicolumn{3}{|c|}{ As } & & $\mathrm{S}$ & \multicolumn{2}{|c|}{$\mathrm{Fe}$} & \multicolumn{3}{|c|}{ As } & \multicolumn{2}{|r|}{$\mathrm{S}$} \\
\hline 1 & 93 & 100.42 & \multicolumn{2}{|c|}{46.95} & \multicolumn{3}{|c|}{0.00} & & 53.47 & \multicolumn{2}{|c|}{1.01} & \multicolumn{3}{|c|}{0,00} & \multicolumn{2}{|c|}{1,99} \\
\hline 2 & 93 & \begin{tabular}{|l|}
100.41 \\
\end{tabular} & \multicolumn{2}{|c|}{46.81} & \multicolumn{3}{|c|}{0.00} & & 53.60 & \multicolumn{2}{|c|}{1.00} & \multicolumn{3}{|c|}{0,00} & \multicolumn{2}{|c|}{2,00} \\
\hline 3 & 95 & \begin{tabular}{|l|}
99.73 \\
\end{tabular} & \multicolumn{2}{|c|}{46.91} & \multicolumn{3}{|c|}{0.00} & & 52.82 & \multicolumn{2}{|c|}{$\frac{1.00}{1.01}$} & \multicolumn{3}{|c|}{0,00} & \multicolumn{2}{|c|}{$\frac{2,00}{1,99}$} \\
\hline & & & & & Мел & Іьник & КОвИТ & пир & ит $-\mathrm{Fe}_{0.92}$ & $\mathrm{~b}_{0.12} \mathrm{~S}$ & & & & & & \\
\hline & & & $\mathrm{Fe}$ & & & $\mathrm{Pb}$ & & & $\mathrm{S}$ & & $\mathrm{Fe}$ & & $\mathrm{Pb}$ & & & $\mathrm{S}$ \\
\hline 4 & 95 & 90.64 & 35.7 & & & 10.51 & & & 42.46 & & .95 & & 0,08 & & & 97 \\
\hline 5 & 95 & 90.46 & 36.0 & & & 10.26 & & & 42.88 & & 95 & & $0.0^{\prime}$ & & & .98 \\
\hline 6 & 95 & 95.38 & 40.4 & & & 5.84 & & & 47.83 & & 97 & & 0,0 & & & 1,99 \\
\hline & & & & & & Халь & копи & UT - & $-\mathrm{Cu}_{0.97} \mathrm{Fe}_{1 .}$ & $\mathrm{S}_{2.02}$ & & & & & & \\
\hline & & & $\mathrm{Cu}$ & & $\mathrm{Fe}$ & $\mathrm{Pb}$ & & & $\mathrm{S}$ & $\mathrm{Cu}$ & & $\mathrm{Fe}$ & $\mathrm{Pb}$ & $\mathrm{Zn}$ & & $\mathrm{S}$ \\
\hline 7 & 95 & 100.08 & 33.54 & & 30.92 & 0.00 & & & 35.62 & 0.96 & & 1.01 & 0.00 & 0.0 & & 2.03 \\
\hline 8 & 95 & 99.96 & 31.59 & & 28.65 & 6.30 & & & 33.42 & 0.95 & & 0.99 & 0.06 & 0.0 & & 2.00 \\
\hline 9 & 117 & 100.05 & 33.99 & & 30.92 & 0.00 & & & 35.14 & 0.98 & & 1.01 & 0.00 & 0.0 & & 2.01 \\
\hline & & & & & & Сфа & алерь & $T-Z$ & $\mathrm{Zn}_{0.85} \mathrm{Fe}_{0.13}$ & 1.01 & & & & & & \\
\hline & & & $\mathrm{Ag}$ & $\mathrm{Cu}$ & $\mathrm{Fe}$ & & $\mathrm{Zn}$ & $\mathrm{C}$ & $\mathrm{S}$ & $\mathrm{Ag}$ & $\mathrm{Cu}$ & $\mathrm{Fe}$ & & $\mathrm{Zn}$ & $\mathrm{Cd}$ & $\mathrm{S}$ \\
\hline 10 & 116 & 99.60 & 0.00 & 2.23 & 6.24 & & 57.84 & 0.0 & \begin{tabular}{|l|l|}
00 & 33.29
\end{tabular} & 0.00 & 0.03 & 0.1 & & 0.85 & 0.00 & 1.00 \\
\hline 11 & 116 & 99.80 & 0.00 & 0.00 & 7.18 & & 58.62 & 0.0 & 0034.00 & 0.00 & 0.00 & 0.1 & & 0.86 & 0.00 & 1.02 \\
\hline 12 & 116 & 99.36 & 0.00 & 0.00 & 7.53 & & 57.99 & 0.0 & \begin{tabular}{|l|l|}
00 & 33.84 \\
\end{tabular} & 0.00 & 0.00 & 0.1 & & 0.85 & 0.00 & 1.02 \\
\hline & & & & & & & Гале & ИT - & $-\mathrm{Pb}_{1.07} \mathrm{~S}_{0.93}$ & & & & & & & \\
\hline & & & $\mathrm{Ag}$ & & $\mathrm{Cu}$ & $\mathrm{Fe}$ & & & $\mathrm{S}$ & $\mathrm{Ag}$ & & $\mathrm{Cu}$ & $\mathrm{Fe}$ & $\mathrm{Pb}$ & & $\mathrm{S}$ \\
\hline 13 & 119 & 100.00 & 13.6 & & 0.00 & 0.00 & & & 12.50 & 0.29 & & 0.00 & 0.00 & 0.8 & & 0.89 \\
\hline 14 & 119 & 100.00 & 17.9 & & 0.78 & 0.00 & & & 12.50 & 0.37 & & 0.03 & 0.00 & 0.7 & & 0.87 \\
\hline 15 & 119 & 100.00 & 24.3 & & 0.00 & 0.00 & & & 12.40 & 0.49 & & 0.00 & 0.00 & 0.6 & & 0.84 \\
\hline & & & & Fe & етраэдр & оит - & $-(\mathrm{Ag}$ & 7 & $6.19)_{9.31}(\mathrm{Fe}$ & $\mathrm{Zn}_{1.4}$ & ${ }_{1.94} \mathrm{Sl}$ & $\mathrm{b}_{3.76} \mathrm{~S}_{12}$ & & & & \\
\hline & & & $\mathrm{Ag}$ & $\mathrm{Cu}$ & $\mathrm{Fe}$ & & $\mathrm{Zn}$ & $\mathrm{Sl}$ & $\mathrm{S}$ & $\mathrm{Ag}$ & $\mathrm{Cu}$ & $\mathrm{Fe}$ & $\mathrm{Zn}$ & As & $\mathrm{Sb}$ & $\mathrm{S}$ \\
\hline 16 & 95 & 98.22 & 17.32 & 25.35 & 0.70 & & 6.19 & 25. & \begin{tabular}{|l|l|}
16 & 23.50
\end{tabular} & 2.90 & 7.20 & 0.23 & 1.71 & 0.00 & 3.73 & 13.23 \\
\hline 17 & 95 & 98.46 & 19.05 & 24.05 & 0.52 & & 6.41 & 25 . & \begin{tabular}{|l|l|}
16 & 23.27 \\
\end{tabular} & 3.21 & 6.88 & 0.17 & 1.78 & 0.00 & 3.76 & 13.20 \\
\hline 18 & 106 & 98.57 & 20.10 & 21.57 & 1.57 & & 5.01 & 26. & $\begin{array}{ll}42 & 22.57 \\
\end{array}$ & 3.38 & 6.16 & 0.51 & 1.39 & 0.00 & 3.94 & 12.77 \\
\hline & & & & & & & Camo & ОДН & Iое золото & & & & & & & \\
\hline & & & $\mathrm{Au}$ & $\mathrm{A}_{\varepsilon}$ & & $\mathrm{Au}$ & $\mathrm{Ag}$ & & & & & & & & & \\
\hline 19 & 93 & 97.92 & 53.11 & 44.8 & & 39 & 0.6 & & & & & & & & & \\
\hline 20 & 117 & 98.68 & 49.27 & 49. & & .35 & 0.6 & & & & & & & & & \\
\hline 21 & 117 & 100.59 & 51.11 & 49. & & .36 & 0.6 & & & & & & & & & \\
\hline
\end{tabular}

Примечание. Аналитик Е. М. Горячева, Саmebax, ЦКП СВКНИИ ДВО РАН, г. Магадан, 2020. 
$a$

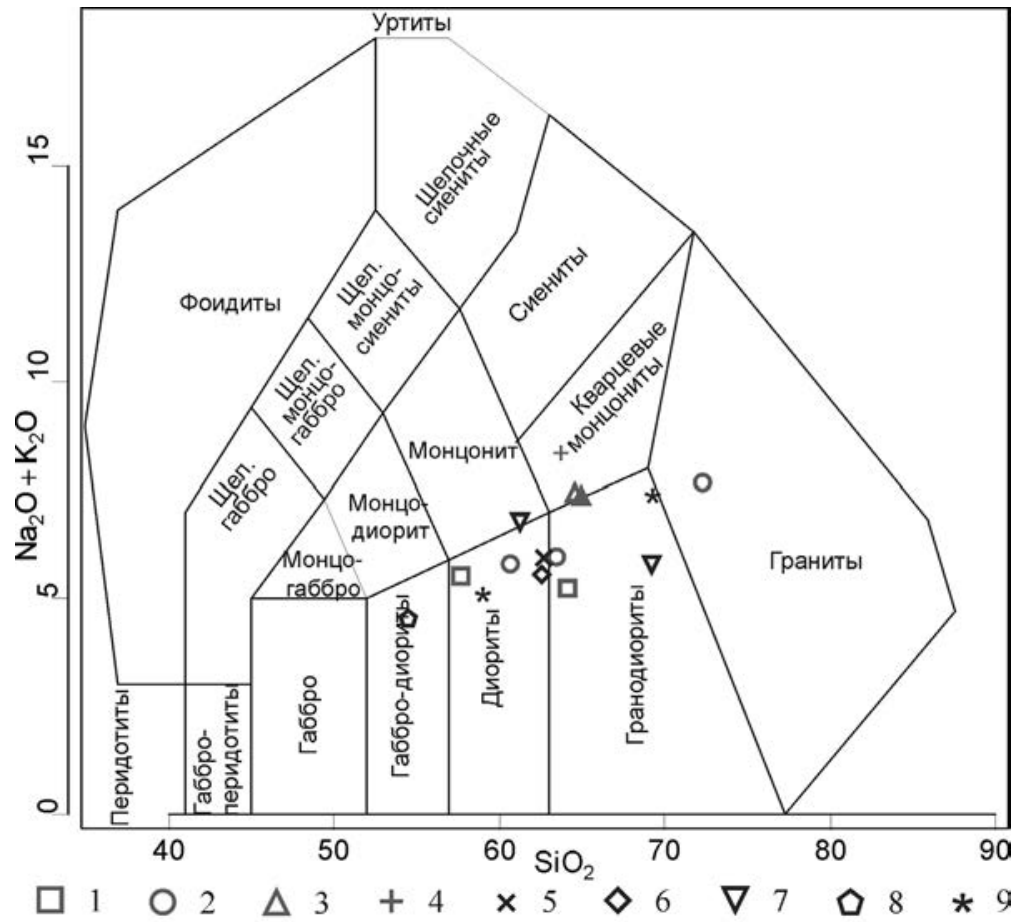

$\sigma$

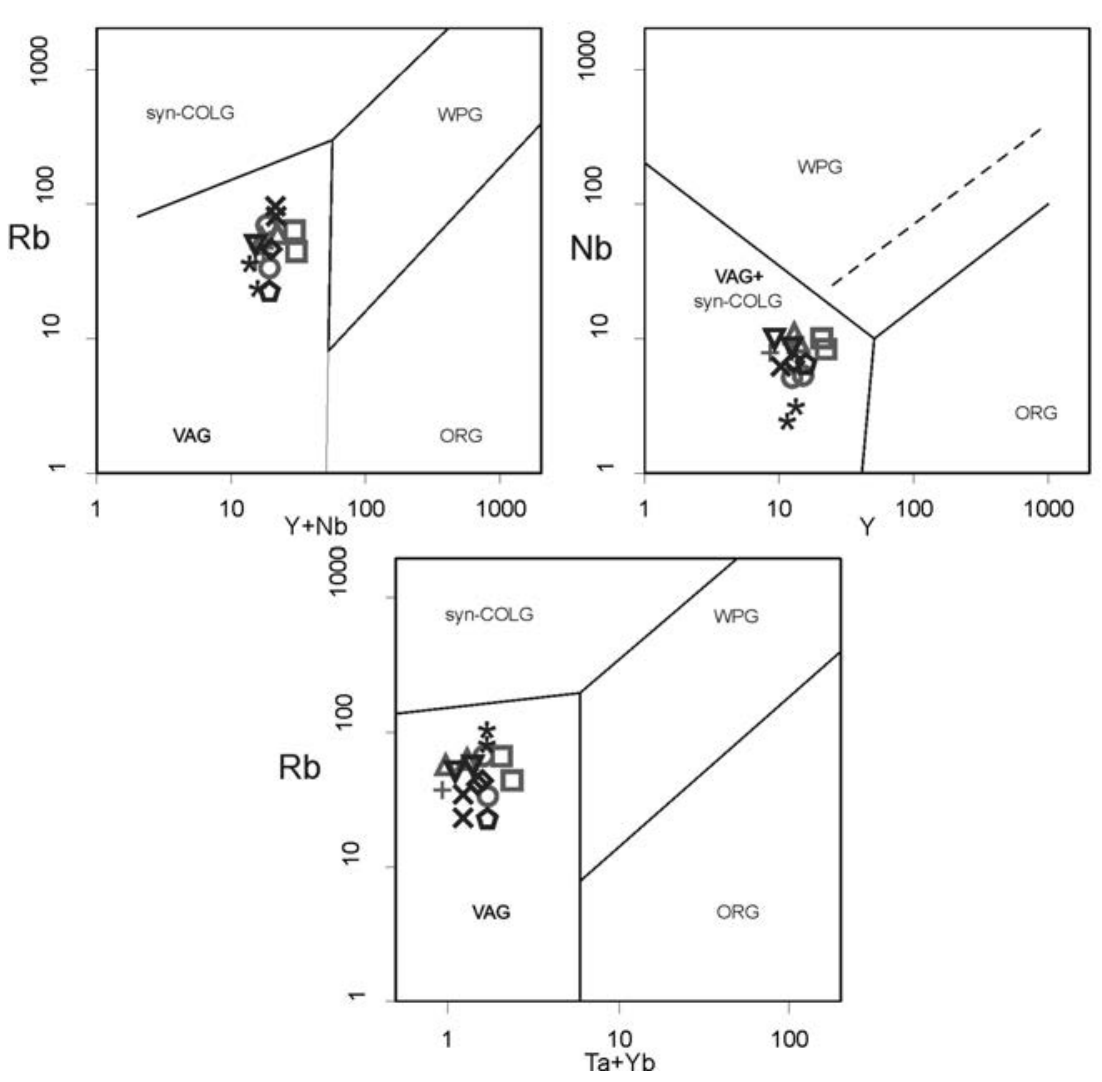

Puc. 9. Диаграмма TAS (a; Middlemost, 1994) и дискриминационные Rb/Y $+\mathrm{Nb}, \mathrm{Nb} / \mathrm{Y}, \mathrm{Rb} / \mathrm{Ta}+\mathrm{Yb}$ диаграммы (б; Pearce et al., 1984) для гранитоидов месторождений и рудопроявлений Конгинской зоны (1-4) и Пенжинского сегмента ОЧВП (5-9): 1 - Захаренковское, 2 - Лабазное, 3 - Седое, 4 - Джелты, 5 - Невенрекан, 6 - Перекатное, 7 - Горное, 8 - Альдигич, 9 - Туромча. Абрревиатуры составов гранитоидов на диаграмме Пирса: syn-COLG - коллизионные, WPG - внутриплитные, VAG - магматических дуг, ORG - океанических хребтов

Fig. 9. TAS ( $a$; Middlemost, 1994) and discriminated Rb/Y $+\mathrm{Nb}, \mathrm{Nb} / \mathrm{Y}, \mathrm{Rb} / \mathrm{Ta}+\mathrm{Yb}$ (б; Pearce et al., 1984) diagrams for granitoids from different deposits of the Kongin zone (1-4) and the OCVB Penzhina segment (5-9): 1 Zakharenko, 2 - Labaznoye, 3 - Sedoye, 4 - Dzhelty, 5 - Nevenrekan, 6 - Perekatnoye, 7 - Gornoye, 8 - Al'digitch, 9 - Turomcha. Abbreviated types of granitoids on the Pearce diagram: syn-COLG - collision, WPG - intraplate, $\mathrm{VAG}$ - volcanic arc, ORG - ocean ridge 
Для сопоставления с Конгинской зоной нами был изучен также петрогеохимический состав меловых гранитоидных интрузий Пенжинского сегмента ОЧВП, развитых на нескольких рудных объектах различного геологогенетического типа. Это золото-серебряные месторождения Невенрекан (Прийменко и др., 2020) и Альдигич (адуляр-серицитовый тип, или низко сульфидированный по международной классификации), Туромча (алуниткварцевый тип, или высоко сульфидированный), золото-редкометалльные месторождение Перекатное и рудопроявление Горное. Гранитоиды относятся к гармандинскому интрузивному комплексу и прорывают завершающие в данном сегменте ОЧВП игнимбриты риолитов хайчанской толщи (Русакова, 2009). Как видно на диаграммах (рис. 9), содержания главных является характерным для зон, развивающихся поперечно к главному простиранию ОЧВП (Акинин и др., 2019). Во-вторых, в пределах Конгинской зоны серебро-полиметаллические рудопроявления намного многочисленнее, нежели золото-серебряные. В свою очередь, последние характеризуются существенно серебряным геохимическим типом (табл. 4) и высокими содержаниями $\mathrm{Pb}$, что также сближает их с сереброполиметаллическими объектами. Объясняются эти отличия, с нашей точки зрения, двумя причинами: (1) большим удалением Конгинской зоны от палеозоны субдукции на континентальной окраине, с которой было связано образование ОЧВП, и (2) влиянием докембрийского гнейсового фундамента ОМ, определившего большую «сиаличность» минерализации Конгинской зоны.

Таблиц̧а 4. Геохимические спектры месторождений и рудопроявлений Конгинской зоны и Пенжинского сегмента ОЧВП

Table 4. Geochemical spectres of ore deposits in the Kongin zone and the OCVB Penzhina segment

\begin{tabular}{|c|c|c|c|}
\hline $\begin{array}{l}\text { Месторождение, } \\
\text { рудопроявление }\end{array}$ & Рудная формация & $\mathrm{Au} / \mathrm{Ag}$ & Спектр \\
\hline \multicolumn{4}{|c|}{ Конгинская зона } \\
\hline Лабазное & Медно-молибден-порфировая & $1: 1$ & Mo-Zn-Au-Pb-Sb-Ag-W \\
\hline $\begin{array}{l}\text { Захаренко } \\
\text { (штокверк) }\end{array}$ & - & $1: 1$ & Mo-Ag-Pb-Cu-Zn-A-gAu \\
\hline Захаренко (жилы) & - & $1: 1$ & $\mathrm{Au}-\mathrm{Pb}-\mathrm{Ag}-\mathrm{W}-\mathrm{Mo}-\mathrm{As}$ \\
\hline Седое & Серебро-полиметаллическая & $1: 1000-1: 5000$ & Pb-Ag-Zn-As-Bi-W-Sb \\
\hline Терминэ & - & $1: 150$ & $\mathrm{Ag}-\mathrm{Zn}-\mathrm{Cu}-\mathrm{Pb}-\mathrm{Ag}-\mathrm{Mo}$ \\
\hline Джелты & Золото-серебряная & $1: 40-1: 100$ & $\mathrm{Ag}-\mathrm{Pb}-\mathrm{Au}-\mathrm{As}-\mathrm{Sb}-\mathrm{Zn}-\mathrm{Mo}$ \\
\hline \multicolumn{4}{|c|}{ ОЧВП } \\
\hline Ирбычан & Золото-серебряная & $1: 50$ & $\mathrm{Ag}-\mathrm{Au}-\mathrm{As}-\mathrm{Sb}-\mathrm{Mo}-\mathrm{Pb}-\mathrm{Cu}$ \\
\hline Невенрекан & - & $1: 50$ & $\mathrm{Ag}-\mathrm{Au}-\mathrm{As}-\mathrm{Sb}-\mathrm{Mo}-\mathrm{W}-\mathrm{Cu}$ \\
\hline Ороч & - & $1: 100$ & $\mathrm{Ag}-\mathrm{Au}-\mathrm{Sb}-\mathrm{Cu}-\mathrm{As}-\mathrm{Pb}-\mathrm{Zn}$ \\
\hline Aypa & Серебро-полиметаллическая & $1: 10000$ & Ag-As-Pb-Au-Zn-Sb-Mn \\
\hline Дручак & - & $1: 1000$ & $\mathrm{Zn}-\mathrm{Ag}-\mathrm{Pb}-\mathrm{Au}-\mathrm{As}-\mathrm{W}-\mathrm{Mn}$ \\
\hline Радуга & - & $1: 500$ & $\mathrm{As}-\mathrm{Ag}-\mathrm{Au}-\mathrm{Pb}-\mathrm{Bi}-\mathrm{Zn}-\mathrm{Sb}$ \\
\hline Вулкан & - & $1: 500$ & $\mathrm{~Pb}-\mathrm{Ag}-\mathrm{Au}-\mathrm{Zn}-\mathrm{Cu}-\mathrm{W}-\mathrm{As}$ \\
\hline
\end{tabular}

оксидов и примесных элементов пород викторинского и гармандинского интрузивных комплексов весьма близки, что вместе с данными по возрасту позволяет относить их к единому этапу магматизма ОЧВП.

\section{ВЫВОДЫ}

Ассоциирующие с оруденением гранитоиды Конгинской зоны и Пенжинского сегмента ОЧВП характеризуются сходными геохимией и возрастом. Полученные для конгинских интрузий U-Pb датировки (Глухов и др., 2021) соответствуют так называемому второму импульсу магматической активности ОЧВП (Акинин, Миллер, 2011; Тихомиров, 2020) с геохронологическим интервалом 94-82 млн лет. Набор рудных формаций в рудопроявлениях и месторождениях Конгинской зоны близок таковым в Пенжинском сегменте ОЧВП, но выявлен и ряд отличий. Вопервых, более высокие концентрации Мо в конгинских медно-молибден-порфировых рудах, что

\section{ЛИТЕРАТУРА}

Акинин В. В., Миллер Э. Л. Эволюция известковощелочных магм Охотско-Чукотского вулканогенного пояса // Петрология. 2011. Т. 19, № 3. С. 249-290.

Акинин В. В., Колова Е. Е., Савва Н. Е., Горячев Н. А., Маматюсупов В. Т., Кузнеиов В. М., Альшевский А. В., Ползуненков Г. О. Возраст гранитоидов и ассоциирующего молибден-порфирового оруденения Коркодоно-Наяханской зоны, Северо-Восток России // Вестник Северо-Восточного научного центра ДВО РАН. 2019. № 4. С. 3-8.

Алексеенко А. В., Коробейников С. В., Сидоров В. А. Новые данные о медно-молибден-порфировом оруденении в пределах Омолонского массива // Рудные формации Северо-Востока СССР. Магадан : СВКНИИ, 1990. C. 157-162.

Болдырев М. В., Яранщева Л. М. Хивачское рудное поле - один из нетрадиционных для Северо-Востока типов серебро-полиметаллического оруденения // Материалы по геологии и полезным ископаемым СевероВостока СССР. Магадан : Кн. изд-во, 1991. Вып. 27. C. 276-278. 
Глухов А. Н. Продуктивность золоторудно-россыпных узлов Омолонского и Приколымского террейнов (Северо-Восток Азии) // Вестник СевероВосточного научного центра ДВО РАН. 2020. № 3. C. 11-27. DOI: 10.34078/1814-0998-2020-3-11-27

Глухов А. Н., Прийменко В. В., Котов А. Б., Акинин В. В., Сальникова Е. Б., Ползуненков Г. О. Новые данные о возрасте Конгинской зоны Омолонского террейна (Северо-Восток Азии) // Геология и минеральносырьевые ресурсы Северо-Востока России : Материалы X Всерос. науч.-практ. конф. с междунар. участием, 05-07 апреля 2021 г. Якутск : Издат. дом СВФУ, 2021. (В печати).

Горячев Н. А., Егоров В. Н., Савва Н. Е., Кузнециов В. М., Фомина М. И., Рожков П. Ю. Геология и металлогения фанерозойских комплексов юга Омолонского массива. Владивосток : Дальнаука, 2017. 312 с.

Коваленкер В. А., Борисенко А. С., Прокофьев В. Ю., Сотников В. И., Боровиков А. А., Плотинская О. Ю. Золотоносные порфирово-эпитермальные рудообразующие системы: особенности минералогии руд, флюидный режим, факторы крупномасштабного концентрирования золота // Актуальные проблемы рудообразования и металлогении : тез. докладов Междунар. совещания. Новосибирск : Геос, 2006. С. 103-104.

Кузнецов В. М. Разнопорядковые структуры тектономагматической активизации в Верхояно-Чукотской складчатой области // Вестник Северо-Восточного научного центра ДВО РАН. 2006. № 2. С. 2-12.

Лычагин П. П., Дылевский Е. Ф., Ликман В. Б. Магматизм Омолонского срединного массива // Изв. АН СССР. Сер. геол. 1990. № 7. С. 17-29.

Павлов Г. Ф., Савва Н. Е., Хорин Г. И., Тепльх В. И., Товма И. Т., Жарихин К. Г., Буляков Г. Х. Самородное серебро в россыпях Северо-Востока СССР // Минералы и минеральные парагенезисы пород и руд СевероВостока СССР. Магадан : СВКНИИ ДВНЦ АН СССР, 1986. C. 77-89.

Пак А. М. Порфировое оруденение Южно-Омолонского рудного района // Колыма. 2002. № 4. С. 14-18.

Показаньев В. П., Вялов А. Г., Пчелинцева Р. 3. Вопросы металлогении Абкитского плутона // Материалы по геологии и полезным ископаемым Северо-Востока СССР. Магадан : Кн. изд-во, 1980. Вып. 25. С. 130-137.

Прийменко В. В., Глухов А. Н., Фомина М. И., Михалицына Т. И. Интрузивный этап развития вулканоструктуры и $\mathrm{Au}-\mathrm{Ag}$ оруденения на примере месторождения Невенрекан (Магаданская область, Россия) // Вулканология и сейсмология. 2020. № 5. С. 13-25.
Русакова Т. Б. Меловой магматизм Северо-Восточного Приохотья: геолого-геохронологическая корреляция: автореф. дис. ... канд. геол.-минер. наук. Владивосток, 2009. 43 c.

Савва Н. Е. Минералогия серебра Северо-Востока России. Москва : Триумф, 2018. 518 с.

Савва Н. Е. Серебро-арсенидная формация Омолонского срединного массива (новые данные) // Вестник Северо-Восточного научного центра РАН. 2019. № 4. C. 9-17.

Тихомиров П. Л. Меловой окраинно-континентальный магматизм Северо-Востока Азии и вопросы генезиса крупнейших фанерозойских провинций кремнекислого вулканизма. Москва : ГЕОС, 2020. 376 с.

Травин А. В., Юдин Д. С., Владимиров А. Г., Хромых С. В., Волкова Н. И., Мехоношин А. С., Колотилина Т. Б. Термохронология Чернорудской гранулитовой зоны (Ольхонский регион, Западное Прибайкалье) // Геохимия. 2009. Т. 11. С. 1181-1199.

Фадеев А. П. Магнетитовые скарны ручья Хрустального (Омолонский массив) // Материалы по геологии и полезным ископаемым Северо-Востока СССР. Магадан : Кн. изд-во, 1974. Вып. 21. С. 319-321.

Фадеев А. П., Розенблюм И. С., Сосунов Г. М., Кузнецов B. M. Зоны тектоно-магматической активизации мезозоид Северо-Востока СССР и их рудоносность // Металлогения и рудные формации зоны перехода континент - океан. Магадан : СВКНИИ ДВО АН СССР, 1990. C. 142-150.

Janoušek V., Farrow C. M., Erban, V. Interpretation of whole-rock geochemical data in igneous geochemistry: introducing Geochemical Data Toolkit (GCDkit) // Journal of Petrology. 2006. 47. 1255-1259.

Ludwig K. R. Isoplot 3.00 A geochronological toolkit for Microsoft Excel. Berkeley : Berkeley Geochronology Center, 2003. $70 \mathrm{p}$.

Lundington S., Plumlee G. S. Climax-type Porphyry Molybdenum Deposits. USGS Open-File Report 20091215. $16 \mathrm{p}$.

Middlemost E. A. K. Naming material in the magma/ igneous rock system // Earth-Science Reviews. 1994. Vol. 37. P. 215-224.

Pearce J. A., Harris N. B., Tindle A. G. Trace elements discrimination diagrams for the tectonic interpretation of granitic rocks // Journal of Petrology. 1984. Vol. 25. P. 956-983.

Sillitoe $R$. H., Hedenquist $J$. $W$. Linkages between volcanotectonic setting, ore-fluid composition and epitermal precious-metals deposits // SEG Special Publication. 2003. 10. P. 315-343.

Поступила в редакиию 13.05.2021 г.

Поступила после доработки 24.05.2021 2.

\title{
METALLOGENY OF THE KONGIN ZONE OF THE OMOLON TERRANE (North-East Asia)
}

\author{
A. N. Glukhov, V. V. Priymenko, M. I. Fomina, V. V. Akinin
}

\author{
North-East Interdisciplinary Scientific Research Institute n. a. N. A. Shilo, FEB RAS, Magadan
}

The article presents new data on geology, mineralogy, and geochemistry of porphyry-copper, goldsilver, and silver-polymetallic ore occurrences in the Kongin magmatic zone of the Omolon terrane and granitoids, associated with it. It has been demon-strated that petrology and the age of granitoids are similar to those in the OCVB Penzhina segment. Mineralization of the Kongin zone is very close 
to that of the OCVB, differing in relatively high Mo in porphyry-copper ores and prevalence of silver-polymetallic mineralization over gold-silver.

\section{Keywords: granitoids, mineralization, ore formation.}

\section{REFERENCES}

Akinin, V. V., Miller, E. L., 2011. Evolution of CalcAlcaline Magmas of the Okhotsk-Chukotka Volcanic Belt, Petrology. 19 (3), 237-277.

Akinin, V. V., Kolova, E. E., Savva, N. E., Goryachev, N. A., Mamatyusupov, V. T., Kuznetsov, V. M., Alshevsky, A. V., Polzunenkov, G. O., 2019. Age of Granitoids and Associated Molybdenum-Porphyry Mineralization in the Korkodon-Nayakhan Zone, North-East of Russia, Bulletin of the North-East Science Center. 4, 3-8. DOI: 10.34078/1814-0998-2019-4-3-8 [In Russian].

Alekseenko, A. V., Korobeynikov, S. V., Sidorov, V. A., 1990. New Data on Porphyry-Copper Mineralization within the Omolon Massif, Ore Formation in the NorthEast of the USSR. Magadan, SVKNII DVO AN USSR. 157-162 [In Russian].

Boldyrev, M. V., Yarantseva, L. M., 1991. Khivach Ore Field - One of Silver-Lead-Zinc Mineralization Types Unconventional for the North-East, Materials on Geology and Mineral Resources in the North-East of the USSR. Magadan. 27, 276-278 [In Russian].

Fadeev, A. P., 1974. Magnetite Skarns of the Khrustalny Creek (Omolon Massif), Materials on Geology and Mineralization in the North-East of the USSR. Magadan. 21, 319-321 [In Russian].

Fadeyev, A. P., Rozenblum, I. S., Sosunov, G. M., Kuznetsov, $V . M ., 1990$. Zones of Tectonic-Magmatic Activization of Mesozoids in the North-East of the USSR and Their Ore-Bearing, Metallogeny and Ore Formations of the Continent - Ocean Transition Zone. Magadan, SVKNII DVO AN USSR. 142-150 [In Russian].

Franklin, J. M., Kissin, S. A., Smyk, M. C., Scott, S. D., 1986. Silver Deposits Associated with Proterozoic Rocks of the Thunder Bay District, Ontario, Canadian Journal of Earth Sciences. 23, 1576-1591.

Glukhov, A. G., 2020. Productivity of Gold-Ore-Areas of the Omolon and Kolyma Terrains (Northeast Asia), Bulletin of the North-East Science Center. 3, 11-27. DOI: 10.34078/1814-0998-2020-3-11-27 [In Russian].

Glukhov, A. N., Priymenko, V. V., Kotov, A. B., Akinin, V. V., Sal'nikova, E. B., Polzunenkov, G. O., 2021. New Data on the Konginskaya Zone of Omolon Terrain (NorthEast Russia), Geology and Mineral Resources in the NorthEast of the Russia, Materials of the 10 ${ }^{\text {th }}$ All-Russia Conference, April 5-7, 2021. Yakutsk. In Press [In Russian].

Goryachev, N. A., Egorov, V. N., Savva, N. E., Kuznetsov, V. M., Fomina, M. I., Rozhkov, P. Yu., 2017. Geology and Metallogeny of Phanerozoic Assemblages of the Omolon Microcontinent's South. Vladivostok, Dalnauka [In Russian].

Janoušek, V., Farrow, C. M., Erban, V., 2006. Interpretation of Whole-Rock Geochemical Data in Igneous Geochemistry: Introducing Geochemical Data Toolkit (GCDkit), Journal of Petrology. 47, 1255-1259.

Kovalenker, V. A., Borisenko, A. S., Prokofiev, V. Yu., Sotnikov, V. I., Borovikov, A. A., Plotinskaya, O. Yu., 2006. Gold-Bearind Porphyry-Epithermal Ore-Forming Systems: Peculiarities of Ore Mineralogy, Fluid Regime, and Factors of Gold Concentration, Actual Problems Ore Formation and Metallogeny, Proceedings of International Conference. Novosibirsk, Geos. 103-104 [In Russian].
Kuznetsov, V. M., 2006. Different-Order Structures of Tectonic and Magmatic Activization in the VerkhoyanskChukotka Folding Area, Vestnik NESC FEB RAS. 2, 2-12 [In Russian].

Ludwig, K. R., 2003. Isoplot 3.00 A Geochronological Toolkit for Microsoft Excel. Berkeley, Berkeley Geochronology Center.

Lundington, S., Plumlee, G. S. Climax-type Porphyry Molybdenum Deposits. USGS Open-File Report 20091215.

Lychagin, P. P., Dylevskiy E. F., Likman V. B., 1990. Magmatism of Omolon Massif, Izvestiya AN USSR. 7, 17-29 [In Russian].

Middlemost, E. A. K., 1994. Naming Material in the Magma/Igneous Rock System, Earth-Science Reviews. 37, 215-224.

Pak, A. M., 2002. Porphyry Mineralization of the South-Omolon District, Kolyma. 4, 14-18 [In Russian].

Pavlov, G. F., Savva, N. E., Khorin, G. I., Teplykh, V. I., Tovma, I. T., Zharikhin, K. G., Bulyakov, G. Kh., 1986. Native Silver in Placers of North-East, Minerals and Mineral Associations of Rocks and Ores of the North-East of the USSR. Magadan, SVKNII DVNC AN USSR. 77-89 [In Russian].

Pearce, J. A., Harris, N. B., Tindle, A. G., 1984. Trace Elements Discrimination Diagrams for the Tectonic Interpretation of Granitic Rocks, Journal of Petrology. 25, 956-983.

Pokazanyev, V. P., Vyalov, A. G., Pchelintseva, R. Z., 1980. Issues in Metallogeny of the Abkit Intrusive, $M a-$ terials on Geology and Mineral Resources in the NorthEast of the USSR. Magadan. 25, 130-137 [In Russian].

Priymenko, V.V., Glukhov, A. N., Fomina, M. I., Mikhalitsyna, T. I., 2020. The Intrusive Phase in the Evolution of the Volcanic Structure and the Au-Ag Mineralization Exemplified bu the Nevenrekan Deposit, Magadan Oblast, Journal of Volcanology and Seismology. 14 (5), 292-304.

Rusakova, T. B., 2009. Cretaceous Magmatism of Northeastern Priokhotye: Geological and Geochronological Correlation. Avtoref. Dis. ... Cand. Geol.-Miner. Nauk. Vladivostok [In Russian].

Savva, N. E., 2018. Mineralogy of Silver in Northeast Russia. Moscow, Triumph [In Russian].

Savva, N. E., 2019. Silver-Arsenide Formation of the Omolon Massif (New Data), Bulletin of the North-East Science Center. 4, 9-17. DOI: 10.34078/1814-09982019-4-9-17 [In Russian].

Sillitoe, R. H., Hedenquist, J. W., 2003. Linkages between Volcanotectonic Setting, Ore-Fluid Composition and Epitermal Precious-Metals Deposits, SEG Special Publication. 10, 315-343.

Tikhomirov, P. L., 2020. Cretaceous Continental-Margin Magmatism in Northeast Asia and Issues in Genesis of the Largest Phanerozoic Provinces of Siliceous Volcanism. Moscow, Geos [In Russian].

Travin, A. V., Yudin, D. S., Vladimirov, A. G., Khromykh, S. V., Volkova, N. I., Mekhonoshin, A. S., Kolotilina, T. B., 2009. Thermochronology of the Chernorudskaya Granulite Zone, Ol'khon Region, Western Baikal Area, Geochemistry International. 47 (11), 1107-1124. 